\title{
Spawning pattern variability and its effect on retention, larval growth and recruitment in Georges Bank cod and haddock
}

\author{
R. G. Lough ${ }^{1, *}$, C. G. Hannah ${ }^{3}$, P. Berrien ${ }^{2}$, D. Brickman ${ }^{3}$, J. W. Loder ${ }^{3}$, J. A. Quinlan ${ }^{4}$ \\ ${ }^{1}$ Northeast Fisheries Science Center, 166 Water St., Woods Hole, Massachusetts 02543, USA \\ ${ }^{2}$ Northeast Fisheries Science Center, James J. Howard Marine Science Laboratory, Magruder Road, \\ Highlands, New Jersey 07732, USA \\ ${ }^{3}$ Ocean Sciences Division, Fisheries and Oceans Canada, Bedford Institute of Oceanography, PO Box 1006, \\ Dartmouth, Nova Scotia B2Y 4A2, Canada \\ ${ }^{4}$ Institute of Marine and Coastal Science, Rutgers University, New Brunswick, New Jersey 08901, USA
}

\begin{abstract}
The MARMAP 11-yr time series (1977 to 1987) of cod and haddock egg/larval distributions was used as a basis for examining the consequences of spawning between eastern and western Georges Bank. For each year, from 1978 to 1987, weekly mean flow fields were based on linear interpolation of seasonal velocity fields with wind and upstream boundary-forcing anomalies. Particles were released from the Northeast Peak (NEP) and western Georges Bank (WGB) spawning areas to assess the relative number of larvae retained within the $70 \mathrm{~m}$ isobath after $8 \mathrm{wk}$. A scaled aggregate Georges Bank (AGB) retention index was also created by weighting the relative number of eggs spawned on the eastern and western halves. While there was considerable interannual variability, mean retention for particles released from NEP at the surface $(0$ to $10 \mathrm{~m})$ was low $(<20 \%)$ during winter but increased in the spring to about $50 \%$ by mid-April, declining through May. Mean retention at $30 \mathrm{~m}$, however, was consistently between 30 and $40 \%$. Mean retention of particles from WGB was higher for surface releases than at depth, and reached $50 \%$ during May. The NEP usually had higher retention than WGB, but the WGB releases could contribute significantly to retention, especially near the surface during the winter period, when there was a loss of particles from NEP due to wind. The $2 \mathrm{yr}$ of high recruitment for cod, 1980 and 1985, occurred during periods of high retention over the spawning season, despite the fact that in 1980 spawning was primarily in the eastern area, while, in 1985, spawning was split between the areas. The large year class of haddock in 1978 had high larval retention and the latest seasonal growth optima in the time series, extending through May.
\end{abstract}

KEY WORDS: Georges Bank · Cod · Haddock - Spawning pattern · Larval transport - Growth · Recruitment

Resale or republication not permitted without written consent of the publisher

\section{INTRODUCTION}

\section{Site}

Bank spawners have adapted to gyral circulation patterns so that some of the larvae/juveniles are retained on the bank and sustain the adult populations (O'Boyle et al. 1984, Sherman et al. 1984). Spawning on Georges Bank (Fig. 1) generally peaks in March for cod and in April for haddock. Spawning generally occurs in those areas on the bank that have the longest residence time, $>35 \mathrm{~d}$ in model simulations based on bi-monthly periods of passive particle residence time in days averaged over 10 to $50 \mathrm{~m}$ of the water column, and in January to April where the Northeast Peak is the primary spawning ground (Page et al. 1998). Page et al. (1998) noted that the central part of the bank consistently had the longest residence time and the bank edges had the shortest residence time, with the exception of the northwest corner, which had an increased 


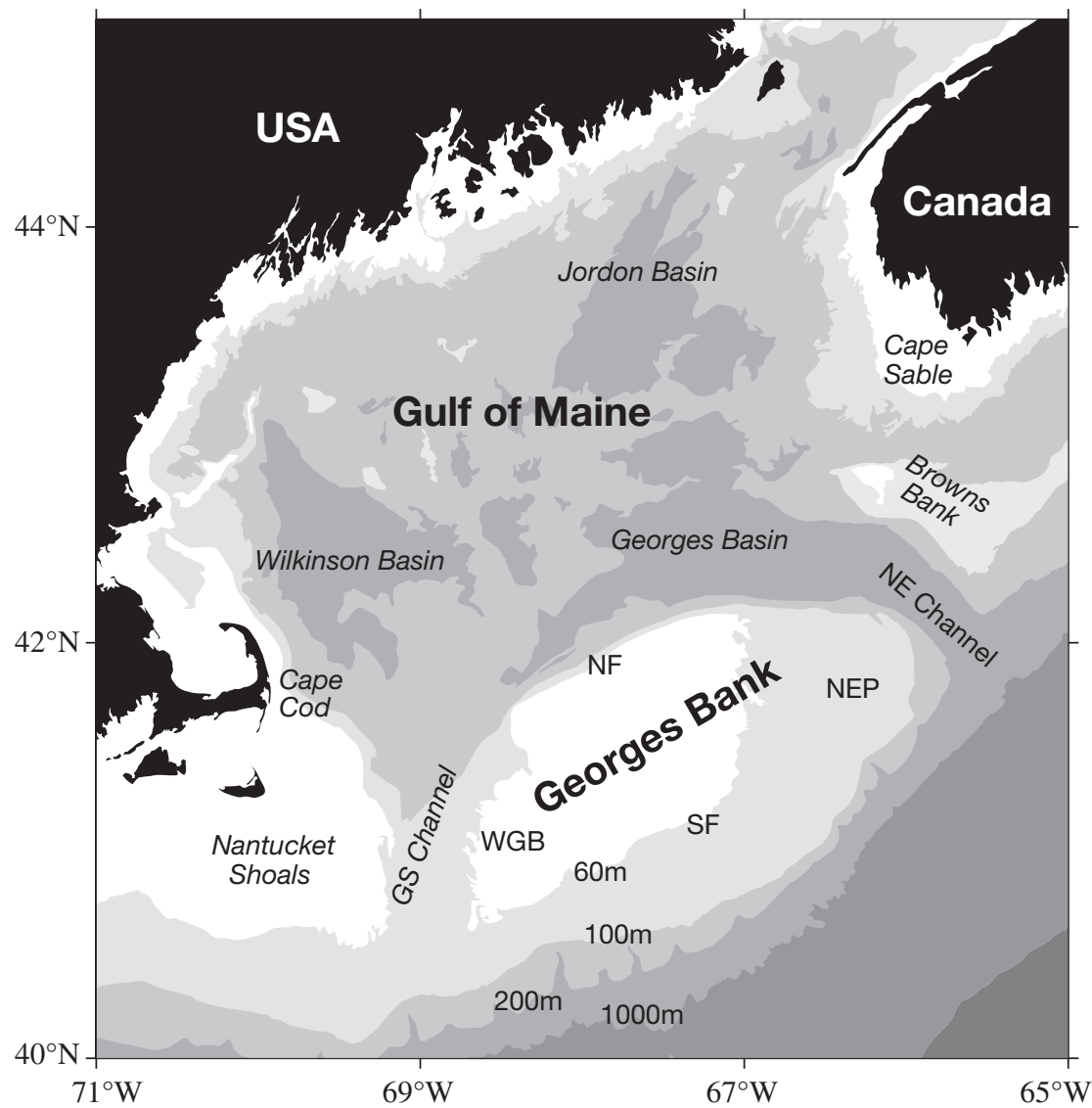

Fig. 1. Map of the Georges Bank and Gulf of Maine region, with subareas on Georges Bank: Northeast Peak (NEP), southern flank (SF), western Georges Bank (WGB), northern flank (NF), Northeast Channel (NE Channel), Great South Channel (GS Channel)

residence time due to the asymmetry associated with the inflow to the gyre. Historically, spawning also has been observed on the northwest corner of Georges Bank for cod and haddock, but not with the same intensity and regularity as on the Northeast Peak. In a variable environment, such as that on Georges Bank, one spawning strategy would be to lengthen the spawning season to spread the risks through time. Another strategy would be to have multiple spawning sites, whereby offshore loss in one area might be compensated by retention in another.

Eggs and larvae of cod and haddock generally drift south and west from the northeast spawning grounds along the southern flank between the 50 and $100 \mathrm{~m}$ isobaths. By mid- to late May, seasonal stratification of the flank water occurs, and the tidal front along the $60 \mathrm{~m}$ isobath separates the shoal well-mixed water from the deeper thermally stratified water. A significant fraction of the eggs and larvae can be transported off the southern edge and presumably lost. A part of the cohort is retained on the shoals of the bank by recirculation on the western end, near the Great South
Channel, when the clockwise circulation pattern intensifies in late spring. In most years significant numbers of larvae are advected across the Great South Channel to Nantucket Shoals.

Lough et al. (1994) compared the influence of wind-driven advection of eggs and larvae in April 1982, when there was an apparent offshore loss of eggs and larvae, and in 1985, when there was little evidence of offshore loss. Cod had a relatively good recruitment at Age 1 for the 1985 year class and poor recruitment for 1982. A 3-dimensional (3D) numerical circulation model was used to track particles in monthly mean flow fields, using the M2 tide, high and low Scotian Shelf inflows, and the 1982 and 1985 monthly mean wind stresses from February through May. Passive, Lagrangian descriptions of the particles were used to examine the effects of variable advection and spawning date on larval distributions for the 2 yr. Results were consistent with the greater loss of eggs/larvae in April 1982 being associated with strong northeast wind stress. Whether a particular wind stress factor and the resultant flow field were good or bad for retention on the bank depended on the location of eggs/larvae on the bank at the time of the event. Cross-bank winds (SE, NW) generally have little influence on along-shelf flow.

Larval retention can be attained in part by convergent circulation patterns, and active behavioral mechanisms of the larvae determine their vertical position (Lough \& Manning 2001). Larvae can be entrained by the seasonal tidal front that develops along the southern flank, which transports them westward and shoalward. Lough \& Bolz (1989) and Lough \& Manning (2001) found evidence for continuous recruitment of both cod and haddock larvae onto the central shoals area $(<60$ to $70 \mathrm{~m})$ of Georges Bank. Based on model simulations by Werner et al. (1993) and Lough \& Manning (2001), larvae were transported westward along the southern flank of the bank and were more likely to be retained on the bank when they occurred shoalward of the $70 \mathrm{~m}$ isobath and in the lower part of the water column, i.e. near the bottom where an onbank residual flow exists. In late spring, when stratification begins over Georges Bank, the gyre intensifies and reinforces the tidally rectified re-circulation pattern (Butman et al. 1987). Hence, both the time and strength of stratification influence the retention of larvae on Georges Bank. 
The recent use of marine protected areas as a new management tool requires knowledge of dispersal patterns of early life stages in order to determine the sustainability of residing populations. It is obvious that multiple spawning sites can offer additional resilience to the population, but more studies are needed on substock structure to define possible Allee effects in aggregate stock-recruitment relationships (Frank \& Brickman 2000).

The purpose of this study was to reexamine the National Marine Fisheries Service MARMAP (Marine Resources Monitoring, Assessment and Prediction) program 1977 to 1987 time series of cod and haddock egg/larval distributions, estimate seasonal abundance and loss rates, and determine the relative contribution of eastern and western spawning sites to total retention on Georges Bank. Indices for bank retention were developed from particle tracking at spawning sites by simulations using realistic 3D prognostic modeled flow fields, estimated weekly from January to June for each year. Retention indices were compared with seasonal spawning and hatching curves, estimated larval growth rates, and 0 -group survivors. Hatching dates of the 0-group survivors were back-calculated from the spawning and hatching curves. Seasonal larval growth rates were also estimated by 2 temperature-based growth models using linearly interpolated temperature fields for Georges Bank subareas.

\section{Georges Bank circulation}

Descriptions of the circulation on Georges Bank may be found in Butman \& Beardsley (1987), Butman et al. (1987), and, for March to April, Werner et al. (1993). Topographic rectification of the strong M2 tidal currents results in a persistent clockwise gyre, which is intensified in summer/fall by the bank's density field. The large-scale coastal current, seasonal mean wind stress and the shelf/slope front contribute to the through-flow in the region, while storms and Gulf Stream rings contribute to episodic outflows from the bank. From February to May, stratification on the bank is weak and gyre strength and recirculation in Great South Channel are near their seasonal minima. Along the bank's steep northern edge, a strong northeastward flow occurs, while, on the southern flank, the southwestward along-bank mean flow increases toward the shelf/slope front at the shelf break. Nearsurface drifter studies from December to April indicate an offshore flow component, with an estimated average residence time for near-surface water on Georges Bank of 45 d. Key features of the bank's physical regime, from the perspective of the modeling strategy, are the interannual persistence of the major circula- tion features, the dominance of forcing by tides and wind, and large-scale through-flow in winter and early spring.

\section{MATERIALS AND METHODS}

Egg and larval data. MARMAP surveys were conducted from 1977 to 1987 at monthly to bi-monthly intervals in the shelf area from Cape Hatteras, North Carolina, USA, to Cape Sable, Nova Scotia, Canada. A $61 \mathrm{~cm}$ bongo fitted with 0.505 and $0.333 \mathrm{~mm}$ mesh nets sampled ichthyoplankton and zooplankton, respectively. Tow profiles were smooth oblique at approximately 1.5 knots to a maximum depth of $200 \mathrm{~m}$, and plankton samples were preserved in $5 \%$ formalin. Flowmeters suspended in the mouths of Bongo nets were used to estimate volume filtered, and maximum tow depth was measured with a bathykymograph. Sampling methods for all aspects of the MARMAP program are described in detail by Sibunka \& Silverman $(1984,1989)$. Egg distribution patterns for the time series can be found in Berrien \& Sibunka (1999).

All fish eggs and larvae were removed from samples, identified to the lowest taxon possible, and then separated into 6 developmental stages (eggs) or measured to the nearest $0.1 \mathrm{~mm}$ (larvae). Although eggs were initially separated into 6 stages, for the purposes of this work, only 3 general stages were used: from fertilization to blastopore almost closed, blastopore closed to embryo encircling $3 / 4$ of the egg's circumference, and $>3 / 4$ around until hatching. Cod and haddock eggs are indistinguishable at developmental stages prior to tail twisting and flexing. Numbers of eggs within these earlier stages were apportioned according to the ratio of older and identifiable stages at the same or adjacent stations.

For this paper's purposes of summarizing egg densities, estimating egg mortality, and subsequently back-calculating numbers spawned and forecasting numbers hatching, egg numbers were grouped into 2 categories: from just fertilized to the embryo encircling $3 / 4$ of the egg's circumference, and a second category of $>3 / 4$ around to hatching. At the typical incubation temperature of $5{ }^{\circ} \mathrm{C}$, these groupings encompass 59 and $41 \%$ of total development time, respectively. Incubation rate data for Atlantic cod are from Thompson \& Riley (1981). Haddock eggs were considered to have the same incubation rates based on other reports, notably Page \& Frank (1989). Duration of the egg stage is typically on the order of $2 \mathrm{wk}$, and from hatching to $10 \mathrm{~mm}$ is about $30 \mathrm{~d}$, and to $15 \mathrm{~mm}, 45 \mathrm{~d}$ (Bolz \& Lough 1988). The dates for the start and end of spawning and hatching in Georges Bank waters were derived from historical collection data (Northeast 
Fisheries Science Center [NEFSC] unpubl. data) in conjunction with the above-noted incubation rates.

Numbers of staged eggs collected in Bongo-net tows were standardized to numbers per $10 \mathrm{~m}^{2}$ of sea surface area to maximum depth of sampling. Stage duration and stage endpoints were calculated for each collection using the mean integrated water-column temperature as the incubation temperature. These values (numbers per $10 \mathrm{~m}^{2}$ and stage endpoints) were averaged for each survey (delta mean numbers per $10 \mathrm{~m}^{2}$ and weighted arithmetic mean stage endpoints). The numbers of days represented by each survey were calculated, weighted by station densities of the stage in question, and centered on the weighted mean date of occurrence for each survey. Season-long mean density and stage endpoint values were calculated, and weighted by station densities and by number of survey days represented.

An average mortality rate was calculated for eggs based on the decline in mean stage density over time (stage median age). The rate was estimated by the fitted exponential rate of decline such that:

$$
X_{t}=X_{0} \mathrm{e}^{-Z t}
$$

where $X_{0}$ is egg density (numbers per $10 \mathrm{~m}^{2}$ ) at Age 0 (at spawning), $X_{t}$ is egg density at Age $t(\mathrm{~d})$, and $Z$ is the instantaneous rate of decline (mortality coefficient).

Percent mortality rate $\left(M, \% \mathrm{~d}^{-1}\right)$ was calculated as:

$$
M=100\left(1-\mathrm{e}^{-z}\right)
$$

This season-long mortality rate was derived from all surveys within a given spawning season. It was assumed that any bias caused by assessing mortality during times of increasing or decreasing spawning rates was effectively countered by using data from all portions of the spawning season. Confidence limits about the slope were not estimated, since there are many sources of uncertainty for meaningful comparisons, as discussed in Mountain et al. (2003).

The estimated mortality rate was used to backcalculate spawned egg densities at each station where earlier-stage eggs were collected. Densities spawned at each station were normalized to daily spawning rates and averaged (delta mean) across all tows in each survey. A weighted mean spawning date was calculated for each survey, and the time interval (days represented) was calculated extending halfway back and forward to adjacent surveys. A seasonal estimate of the eggs spawned was derived by summing the daily spawning rates represented by each survey. Similarly, hatching rates were calculated for each later-stage occurrence, averaged for each survey, expanded over each survey's days represented, and summed over the season.

In order to estimate the relative abundance of spawning between the eastern and western historical spawning grounds, the abundances of egg stages 1 and 2 were estimated by the same methods describe above for the MARMAP surveys, for the period from October through August, for the eastern $\left(26618 \mathrm{~km}^{2}\right)$ and western $\left(24957 \mathrm{~km}^{2}\right)$ halves of Georges Bank, delimited by a line at $67^{\circ} 41^{\prime} \mathrm{W}$.

Since there were no data on eggs available for the 1976-1977 and 1977-1978 spawning seasons, estimates of the initial abundance of larvae at hatch (3.3 mm standard length, SL) from each survey were made from the exponential regression of abundance on age. For all larvae 5 to $15 \mathrm{~mm}$ in length during a given spawning season, collection densities at each $0.1 \mathrm{~mm}$ of length were grouped into $1 \mathrm{~mm}$ intervals and then aged using the age-length relationship derived by Bolz \& Lough (1988). Larval abundance estimates were adjusted to reflect day/night/twilight differences in vulnerability to capture using correction factors derived by Morse (1989). Plots of these summed densities-at-age typically described a decline in density over time. Fitting a curvilinear decay function to these points, $y=a \times \exp (-b x)$, yielded an instantaneous mortality coefficient $(b)$ that was then applied to individual collection densities to estimate corresponding hatching densities for each tow. Similar to methods used for eggs (described above), mean hatching densities per survey were calculated (delta mean) from station values of summed hatching densities, then expanded over the entire season by multiplying normalized (per day) densities by the number of days represented by each survey, and then summing the survey estimates over the season. Mortality rates may be confounded by temperature; however, no adjustment was applied to these estimated mortality rates here because of the uncertainty of various mechanisms involved.

Maps of contoured numbers of egg stages and larval size classes per $10 \mathrm{~m}^{2}$ were created by first $\log _{10}$-transforming the station density (numbers per $10 \mathrm{~m}^{2}+1$ ) and then applying a kriging griding method using Surfer software. The larvae were separated into 4 length classes: $3-5,6-8,9-11$, and $12-15 \mathrm{~mm}$. Mean age and stage duration for the 3 egg and 4 larval length classes are reported in Lough et al. (1994).

Juveniles and adults. Estimates of 0-group abundance are from fall NEFSC groundfish surveys and standardized as the means of stratified catch per tow for haddock $<26 \mathrm{~cm}$ and cod $<32 \mathrm{~cm}$. These upper limits of the 0 -group were based on an estimate of average growth of $17.5 \mathrm{~cm}$ for haddock and $26.1 \mathrm{~cm}$ for cod during their first year of life (Pentila et al. 1989). In order to estimate from which part of the hatching curve the fall survivors may have come, the 0-group hatch dates were back-calculated from the length-frequency distribution of the 0-group using the age-length growth equations of Bolz \& Lough (1988). The Bolz \& 
Lough (1988) age-length equations agreed closely with the size-at-age estimates for haddock young-of-year juveniles derived by otolith ageing techniques (Lapolla \& Buckley 2005).

Time series of cod and haddock recruitment (R) at Age 1, spawning stock biomass (SSB), and recruitment survival (R/SSB) in the Georges Bank region (Fig. 2) were based on virtual population analyses (Northern Demersal Working Group, Northeast Regional Stock Assessment Workshop 2001). In the MARMAP time series, the 1980 and 1985 year classes of cod were the most abundant, followed by the 1983, 1987, and 1978 cohorts. The 1978 year class of haddock had relatively large recruitment, followed by the 1983, 1985, and 1987 year classes. The 1982 and 1984 year classes were commonly bad for both cod and haddock. Recruitment survival was very good for the 1978 year class of haddock, followed by 1987, 1985, and 1983. For cod, the best year of recruitment survival was 1985, followed by 1980, 1987, and 1983. The 1982 and 1984 year classes
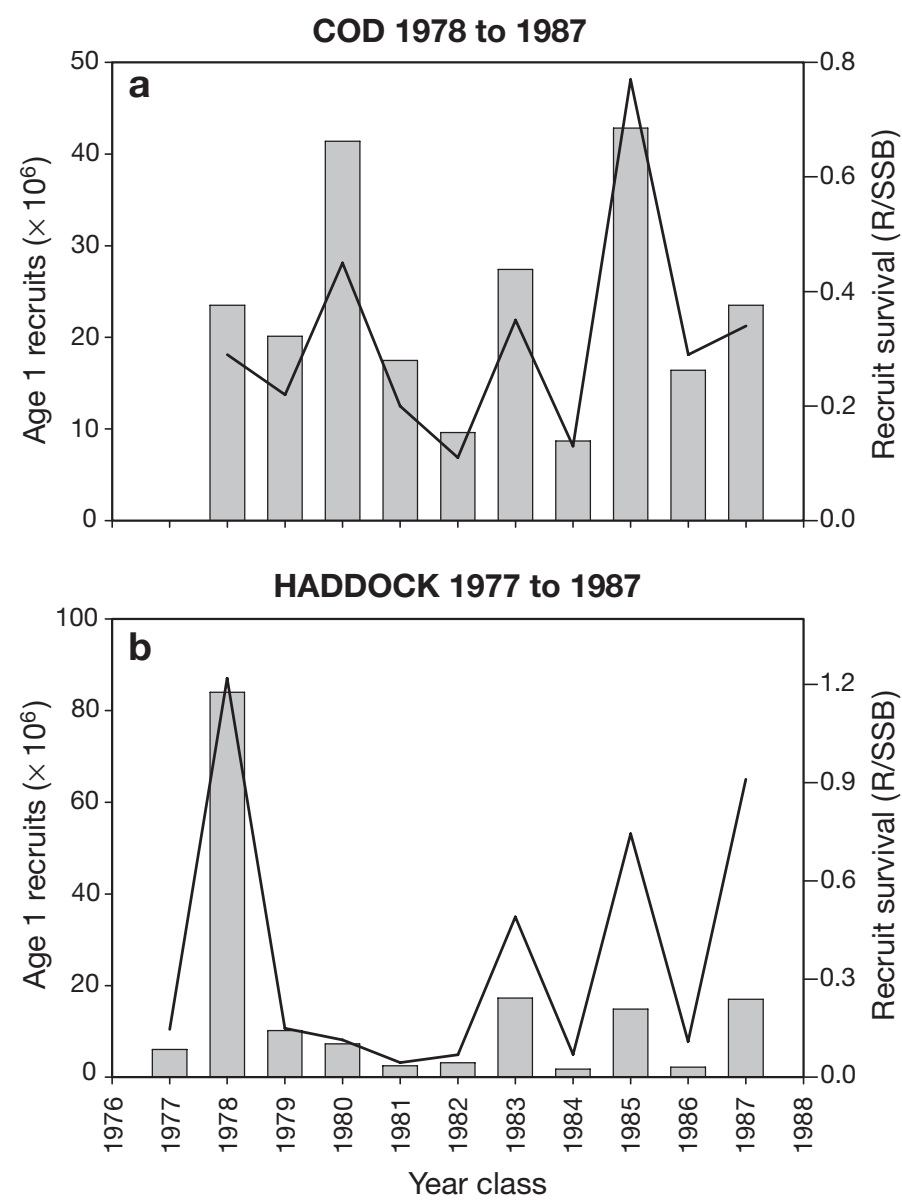

Fig. 2. Age 1 recruitment ( $R$, histograms) and recruitment survival (R/SSB) for Georges Bank (a) cod and (b) haddock during the MARMAP period 1977 to 1987. Data are from virtual population analyses. SSB: spawning stock biomass of both cod and haddock had the lowest recruitment survival.

Circulation estimation. For each year (1978 to 1987), the weekly mean circulation was estimated from January to July (Weeks 1 to 30). The circulation for a given week was a linear combination of 4 components: the seasonal mean circulation, the responses to the along-shelf and cross-shelf wind-stress anomalies, and to anomalous forcing at the upstream boundary. The overall procedure is described in detail in Hannah et al. (2000), where monthly mean circulation was used for the Browns Bank region. A brief description is given here.

The circulation was computed on a model domain extending from the eastern Scotian Shelf to Cape Cod. The weekly estimates of the seasonal mean circulation were based on linear interpolation of velocity fields representing winter (1 February), spring (1 May), and summer (1 August). This component, which is constant across years, is described by Hannah et al. (2001). The circulation around Georges Bank is very similar to that described by Naimie (1996).

The year-to-year variability comes from the windand boundary-forced components. The wind-stress anomalies were computed from the composite time series derived from Gulf of Maine buoy data by Manning \& Strout (2001). The responses to the along- and crossshelf stress anomalies were calculated using a linear 3D barotropic model (Lynch et al. 1992), with specified vertical eddy viscosity and bottom friction coefficients. The boundary elevations were clamped at zero along the upstream and offshore boundary. The vertical mixing coefficients were based on a blend of an empirical upper-ocean profile and the vertical mixing coefficients from the April to May seasonal mean simulation (details are given in Hannah et al. 2000). The bottom friction coefficients were taken as the time-averaged coefficients from the April to May seasonal mean solution plus the additional bottom friction due to $0.10 \mathrm{~m} \mathrm{~s}^{-1}$ of unmodelled flow. The response patterns are similar to those described in Greenberg et al. (1997).

The boundary-forced component is based on weekly mean adjusted sea level (ASL) at Halifax. The anomalies were computed with respect to the weekly means for the period 1978 to 1987 . The component of sea level variability at Halifax due to wind stress over the Scotian Shelf was removed using Sable Island wind stress and the wind model described above. The remaining ASL variability was assigned to the boundary forcing. The velocity response to boundary forcing was calculated using the same linear barotropic model, bottom friction coefficients, and vertical eddy viscosities as used for the wind response calculations. The upstream boundary forcing was specified as a linear elevation decrease from the coast to mid-shelf, with the rest of the upstream and offshore boundary clamped to zero. 
In addition to the weekly mean flow fields, the M2 tidal currents from Hannah et al. (2000) were included in the simulations. The Stokes drift associated with the spatial variations in the tidal currents at the edge of Georges Bank can make an important contribution to the residual drift (Loder 1980).

Retention indices. Particle tracking forms the basis for the calculation of the retention indices. Particles were tracked in the weekly mean and M2 velocity fields using a 4th-order Runge-Kutta method (Werner et al. 1993). The velocity field was partitioned into 2 vertical levels: the average over the upper $10 \mathrm{~m}$ and the $30 \mathrm{~m}$ level. Three scenarios were considered for the vertical distribution: (1) 0 to $10 \mathrm{~m}$ average for $8 \mathrm{wk}$, (2) $30 \mathrm{~m}$ for $8 \mathrm{wk}$, and (3) 0 to $10 \mathrm{~m}$ average for $2 \mathrm{wk}$ followed by $30 \mathrm{~m}$ for $6 \mathrm{wk}$. The third scenario approximates the observation that the eggs and early larval stages are high in the water column and the later stages are lower in the water column. Additional random horizontal kicks were added; these correspond to a horizontal eddy diffusivity of $50 \mathrm{~m}^{2} \mathrm{~s}^{-1}$.

Two distinct release regions were considered: the Northeast Peak (NEP) and western Georges Bank (WGB). For each scenario (release region and vertical distribution), 2 retention indices were computed at 4 and $8 \mathrm{wk}$ : the fraction of particles found inside the $70 \mathrm{~m}$ isobath and the fraction found between the 70 and $200 \mathrm{~m}$ isobaths and east of the westward extent of the $70 \mathrm{~m}$ isobath (to remove the western side of Great South Channel from the retention area). A combined retention index was also created by joining the NEP and WGB indices to reflect the proportional spawning between the 2 areas. In this case, the retention indices for NEP and WGB were weighted by the relative number of cod eggs spawned on the eastern and western halves of the bank, estimated from the MARMAP data (Fig. 3a). The weights are annual averages and are constant for a given year. This accounts for interannual variability in the relative strengths of spawning on the 2 halves of the bank, but does not account for weekly variability, nor does it account for interannual changes in the overall abundance of eggs. Each index is labeled by the spawning date for the cohort of simulated drifters. A weekly mean index was computed for the entire time series (1978 to 1987), and a retention anomaly for each year was derived from the overall weekly mean index by subtraction.

Temperature estimation for the MARMAP years. Temperature and error fields were estimated at 5 and $30 \mathrm{~m}$ for a grid of points covering Georges Bank. The estimation procedure used the data from the Bedford Institute of Oceanography's hydrographic database (Petrie et al. 1996) and 4D optimal interpolation with OAX5 software; see Loder et al. (1997) for details. The
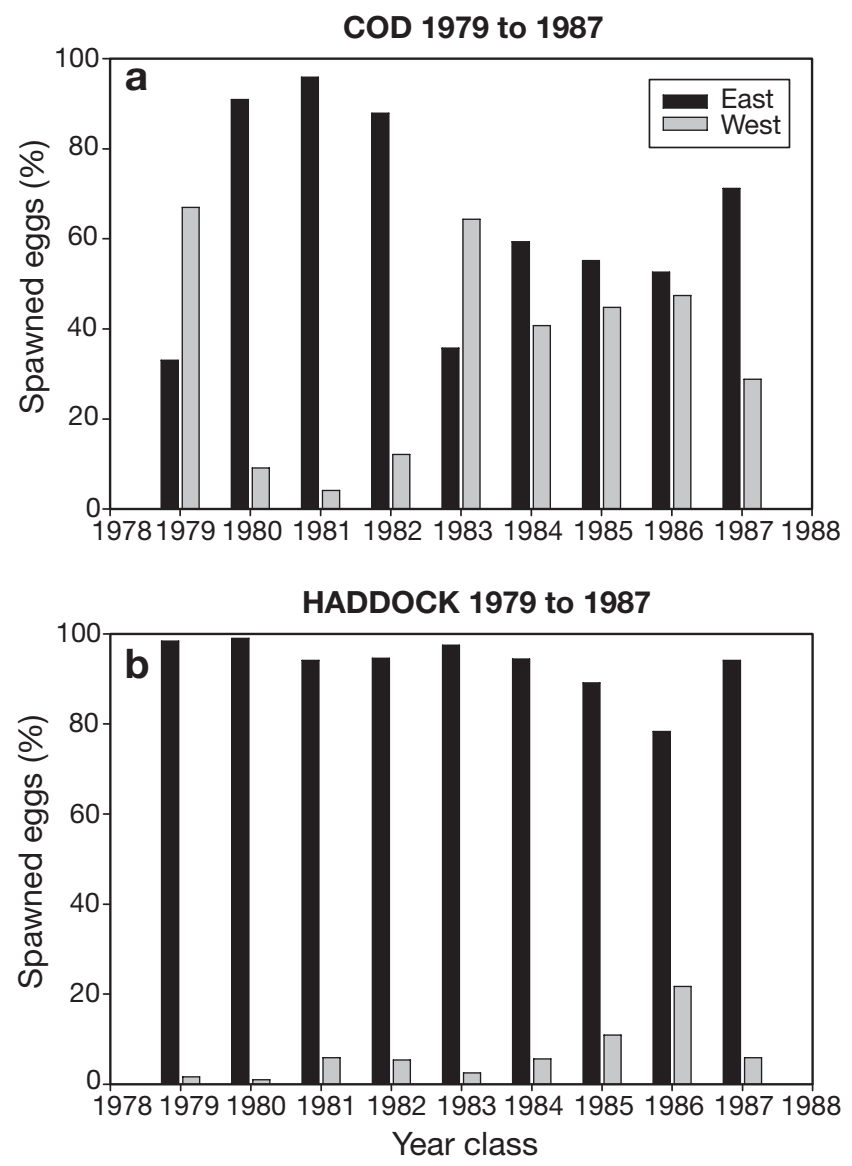

Fig. 3. Relative abundance (\%) of (a) cod and (b) haddock eggs spawned on eastern and western Georges Bank for the 1979 to 1987 spawning seasons

dates of the estimations were centered on peaks of the sampling distribution over 1978 to 1987; generally MARMAP cruises. Thus, the dates assigned to the temperature fields differed from year to year. Temperature time series were created for 5 subarea polygons by calculating the average temperature over grid points; these had a relative estimation error $<30 \%$. The average was retained if at least $50 \%$ of the nodes in the polygon passed the error criterion. Interannual time series for 1 March, 1 April, 1 May, and 1 June were created by linear interpolation on the cruisecentered time series. The 5 polygons are designated Northeast Peak 2 (NEP2), northern Georges Bank (NGB), western Georges Bank (WGB), central Georges Bank (CGB), and southern Georges Bank (SGB).

Growth indices. Using the linearly interpolated temperature field data, larval growth rates were estimated by 2 growth models incorporating a temperature term. Campana \& Hurley (1989), using a logistic growth model, predict length-at-age with a temperature optimum of $5.9^{\circ} \mathrm{C}$ for cod and $6.7^{\circ} \mathrm{C}$ for haddock. More recently, Buckley et al. (2004) fit a parabolic model 
between water temperature and field-measured recent specific growth rate (dry weight protein content $\mathrm{d}^{-1}$ ) of larval cod and haddock on the southern flank to Georges Bank in May 1992 to 1994. For both species, growth was maximum near $7^{\circ} \mathrm{C}$, yielding a domeshaped relationship with temperature. The Campana \& Hurley (1989) growth formulation underestimates field growth rates of larvae based on Bolz \& Lough (1988), so for comparison their growth rates were rescaled to the temperature optimum $\left(7.2^{\circ} \mathrm{C}\right)$ of Buckley et al. (2004). Average growth plots were made comparing the 2 formulations for periods of 1, 2, and $4 \mathrm{wk}$, from March through June for each year (1978 to 1987), for each of the 5 Georges Bank subarea polygons, at 2 depths $(5$ and $30 \mathrm{~m}$ ). Contoured growth plots of the entire Georges Bank area at 5 and $30 \mathrm{~m}$ depths also were made for specific days of the year, such as Day 140 (19 May), to examine the spatial structure of growth when seasonal stratification of the flank water occurs. In some cases there was insufficient temperature data to estimate growth, and in other cases the temperature value was out of range of the Buckley et al. (2004) formulation based on May data.

Table 1. Estimated seasonal egg abundance at spawning and hatching, and loss rates for eggs and larvae of Georges Bank cod and haddock over the $11 \mathrm{yr}$ MARMAP time series of surveys. Larval mortality rates are based on exponential regression of 5 to $15 \mathrm{~mm}$ larvae. Hatching abundance estimates for 1977 and 1978 are based on larval regression to size at hatching. CV = coefficient of variation

\begin{tabular}{|ccccccc|}
\hline Season & $\begin{array}{l}\text { Spawning } \\
\text { abundance } \\
\left(\text { no. } \times 10^{12}\right)\end{array}$ & $\begin{array}{c}\text { CV } \\
(\%)\end{array}$ & $\begin{array}{c}\text { Hatching } \\
\text { abundance } \\
\left(\text { no. } \times 10^{12}\right)\end{array}$ & $\begin{array}{c}\text { CV } \\
(\%)\end{array}$ & $\begin{array}{c}\text { Egg } \\
\text { mortality } \\
\left(\% \mathrm{~d}^{-1}\right)\end{array}$ & $\begin{array}{c}\text { Larval } \\
\text { mortality } \\
\left(\% \mathrm{~d}^{-1}\right)\end{array}$ \\
\hline Cod & & & & & \\
$1976-77$ & No data & & 7.21 & & & 8.6 \\
$1977-78$ & No data & & 33.40 & & & 16.2 \\
$1978-79$ & 11.36 & 35.6 & 2.06 & 43.2 & 17.2 & 5.5 \\
$1979-80$ & 59.08 & 57.3 & 33.03 & 72.3 & 2.7 & 12.3 \\
$1980-81$ & 58.78 & 42.5 & 3.21 & 39.7 & 13.5 & 5.4 \\
$1981-82$ & 55.05 & 46.9 & 0.55 & 36.1 & 19.6 & 16.0 \\
$1982-83$ & 4.76 & 27.5 & 0.88 & 32.8 & 9.5 & 10.4 \\
$1983-84$ & 3.98 & 25.3 & 2.64 & 32.4 & 2.3 & 9.8 \\
$1984-85$ & 4.94 & 24.2 & 2.28 & 34.1 & 4.0 & 7.6 \\
$1985-86$ & 8.94 & 38.1 & 0.83 & 29.9 & 12.3 & 10.1 \\
$1986-87$ & 8.28 & 41.7 & 0.61 & 36.2 & 13.2 & 10.0 \\
& & & & & & \\
$1976-77$ & Noddock & & & & & 10.1 \\
$1977-78$ & No data & & 12279.97 & & & 29.9 \\
$1978-79$ & 17.77 & 49.3 & 2.03 & 42.9 & 10.3 & 14.0 \\
$1979-80$ & 95.04 & 56.1 & 2.07 & 43.1 & 17.2 & 11.5 \\
$1980-81$ & 13.74 & 38.1 & 2.19 & 34.8 & 9.3 & 11.3 \\
$1981-82$ & 4.26 & 30.9 & 0.09 & 37.7 & 16.5 & 17.8 \\
$1982-83$ & 13.98 & 41.2 & 2.40 & 38.7 & 9.7 & 19.1 \\
$1983-84$ & 1.69 & 44.7 & 2.39 & 54.6 & 0.0 & 16.6 \\
$1984-85$ & 3.07 & 32.3 & 1.53 & 38.4 & 3.7 & 9.2 \\
$1985-86$ & 2.61 & 41.3 & 0.98 & 47.4 & 5.3 & 10.5 \\
$1986-87$ & 2.43 & 32.0 & 2.08 & 36.0 & 0.8 & 11.0 \\
& & & & & & \\
\hline
\end{tabular}

\section{RESULTS}

\section{Egg/larval abundance and mortality}

The estimated seasonal egg abundance of cod at spawning ranged from 11 to $59 \times 10^{12}$ for the 1978-1979 through 1981-1982 seasons, but was an order of magnitude lower, 4 to $9 \times 10^{12}$ for $1982-1983$ through 1986-1987 (Table 1). No data on eggs were available for the 1976-1977 and 1977-1978 seasons, so that an initial estimate at hatching was based on the exponential regression of the 5 to $15 \mathrm{~mm}$ larvae. The 1977-1978 and 1979-1980 seasons had the highest hatching abundance of the time series, at $33 \times 10^{12}$. All other years in the time series were an order of magnitude lower in abundance at hatching. Coefficients of variation ranged between 20 and $60 \%$, which is typical for plankton surveys. Cod egg and larval mortality rates ranged between 2 and $20 \% \mathrm{~d}^{-1}$, with no apparent trends. The seasonal egg abundance of haddock at spawning ranged from 1 to $95 \times 10^{12}$; the values in 1979-1980 being the highest (Table 1). The 1978-1979, 1980-1981, and 1982-1983 seasonal estimates were intermediate, 14 to $18 \times 10^{12}$. All other years were very low, 1 to $4 \times 10^{12}$. Abundance at hatching was very high, $12280 \times 10^{12}$, for the 1977-1978 season, based on larval abundance. Hatching abundance estimates for all other years were very low, $<7 \times 10^{12}$; the 1981-1982 season had the lowest hatching abundance $\left(0.09 \times 10^{12}\right)$ in the time series.

\section{Subarea egg abundance}

The relative abundance of cod and haddock eggs spawned on the eastern and western halves of Georges Bank are shown in Fig. 3 for the 1979 to 1987 seasons. Cod spawning was split between east and west, but $>80 \%$ occurred on the eastern half in 1980, 1981, and 1982. More cod spawning occurred on the western half in 1979 and 1983. Haddock, in contrast, spawned predominantly on the eastern half (>80\%).

\section{Modeled retention index (January to June)}

An example of weekly particle distributions from eastern and western spawning release areas (Fig. 4) is shown in Fig. 5 for the last week in March 1985. Particle distributions are shown for NEP2 and WGB at 


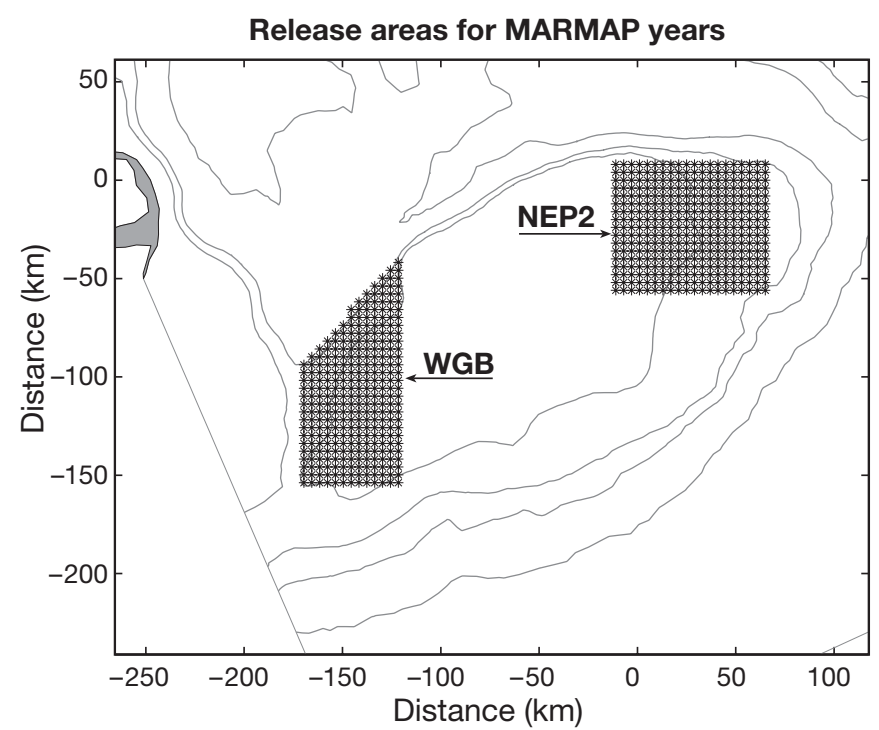

Fig. 4. Release grids for particle drift scenarios covering historic spawning grounds of cod and haddock on Northeast Peak 2 (NEP2) and western Georges Bank (WGB). Grid axes centered on NEP2 southern flank of Georges Bank, with some crossing the Great South Channel. At the surface, some particles were also advected off the southern side beyond the $200 \mathrm{~m}$ isobath, but at $30 \mathrm{~m}$, no particles were observed off the southern side of the bank at 4 or $8 \mathrm{wk}$. For the WGB release site, surface particles mostly moved up along the northern side of the bank and tended to stay within the shoal region of the bank. Particles released at $30 \mathrm{~m}$ also moved up along the northern flank of the bank, but tended to track along the outer perimeter of the bank in an enclosed gyre after $8 \mathrm{wk}$, with few particles retained within the shoal area ( $<60 \mathrm{~m}$ bottom depth). No particles released from the WGB were observed off the southern side of Georges Bank. Particle distributions after $8 \mathrm{wk}$ would be more indicative of advective effects experienced by hatching to late-stage larvae (12 to $15 \mathrm{~mm} \mathrm{SL}$ ), which would generally coincide in timing with the bimonthly MARMAP surveys. Therefore, only examples of the particle distributions after $8 \mathrm{wk}$ are shown below in results from the various release site scenarios.

\section{Northeast Peak 2 (70 m; Figs. 6 \& 7)}

the surface ( 0 to $10 \mathrm{~m}$ ) and $30 \mathrm{~m}$ depth after 4 and $8 \mathrm{wk}$. Surface particles are more indicative of the variable wind forcing. Based upon observed wind stress, the locus of modeled particles from NEP2 was located along the

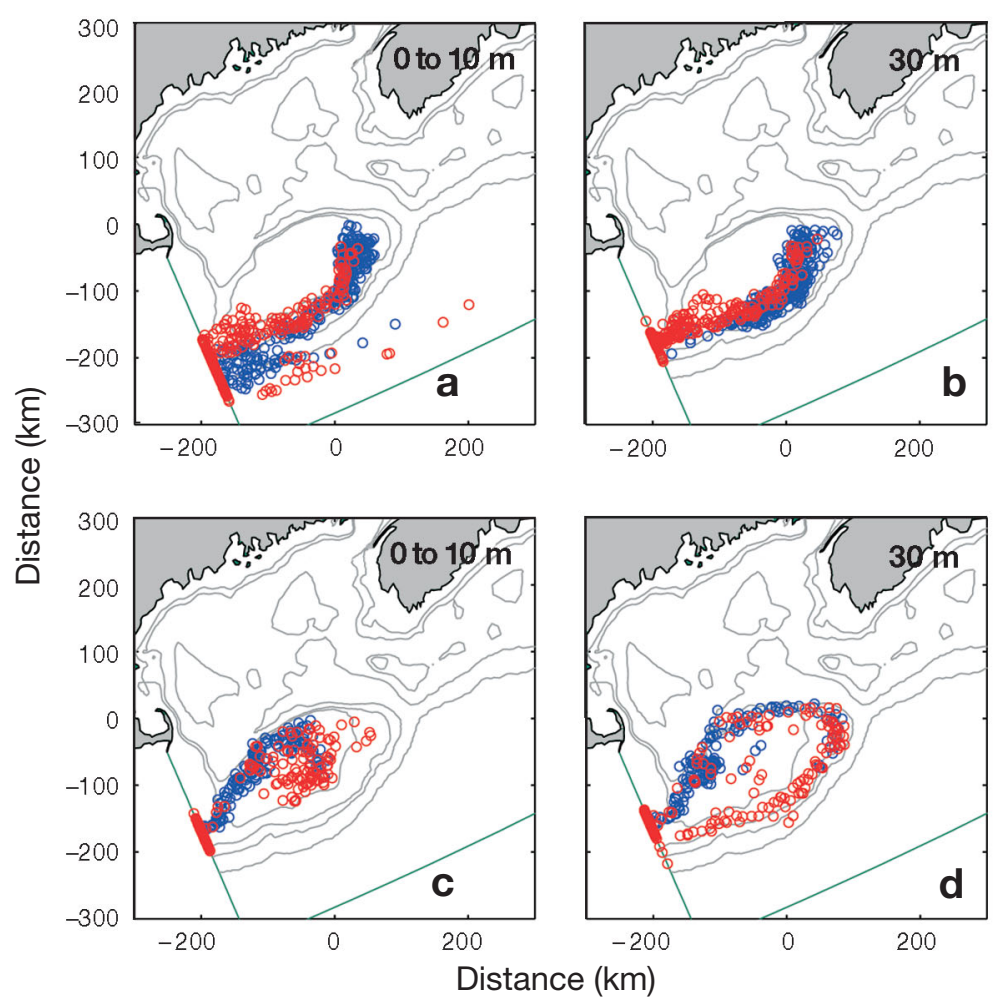

Fig. 5. Examples of particle drift from $(a, b)$ Northeast Peak 2 and $(c, d)$ western Georges Bank in late March (Week 13), 1985, after 4 wk (blue) and $8 \mathrm{wk}$ (red) at 0 to $10 \mathrm{~m}$ and $30 \mathrm{~m}$ depth
Mean retention within the $70 \mathrm{~m}$ isobath of particles released at 0 to $10 \mathrm{~m}$ depth was very low $(<20 \%)$ in the winter and then increased in the spring to about $50 \%$ by mid-April (Week 15), declining through May. Retention at 4 wk was only slightly higher than at $8 \mathrm{wk}$. Mean retention at $30 \mathrm{~m}$, however, was fairly consistent, between 30 and $40 \%$, in both winter and spring, a little more at 4 than at $8 \mathrm{wk}$. The scenario in which particles were kept at the surface for $2 \mathrm{wk}$ and then at $30 \mathrm{~m}$ for $6 \mathrm{wk}$ had a retention intermediate between those of constant-depth releases. The greatest retention occurred at $30 \mathrm{~m}$ at $4 \mathrm{wk}$, in both winter and spring, and at 0 to $10 \mathrm{~m}$ at $4 \mathrm{wk}$, in spring. There was considerable interannual variability in the retention of surfacereleased particles, which could range from 0 to $90 \%$ over the winter/spring period. High positive anomalies at $30 \mathrm{~m}$ occurred in the winters of 1980, 1983, and 1987.

\section{Western Georges Bank (70 m; Fig. 8)}

Mean retention was higher after 4 than after $8 \mathrm{wk}$, and higher at 0 to 10 than at $30 \mathrm{~m}$. While mean retention after $8 \mathrm{wk}$ was about $20 \%$, more retention, 30 to $50 \%$, occurred in the surface layer during May. Retention was lower when particle time was split between 0 to $10 \mathrm{~m}$ and $30 \mathrm{~m}$. The greatest retention 
NEP2: GB70 in: 0 to $10 \mathrm{~m}, 8 \mathrm{wk}$
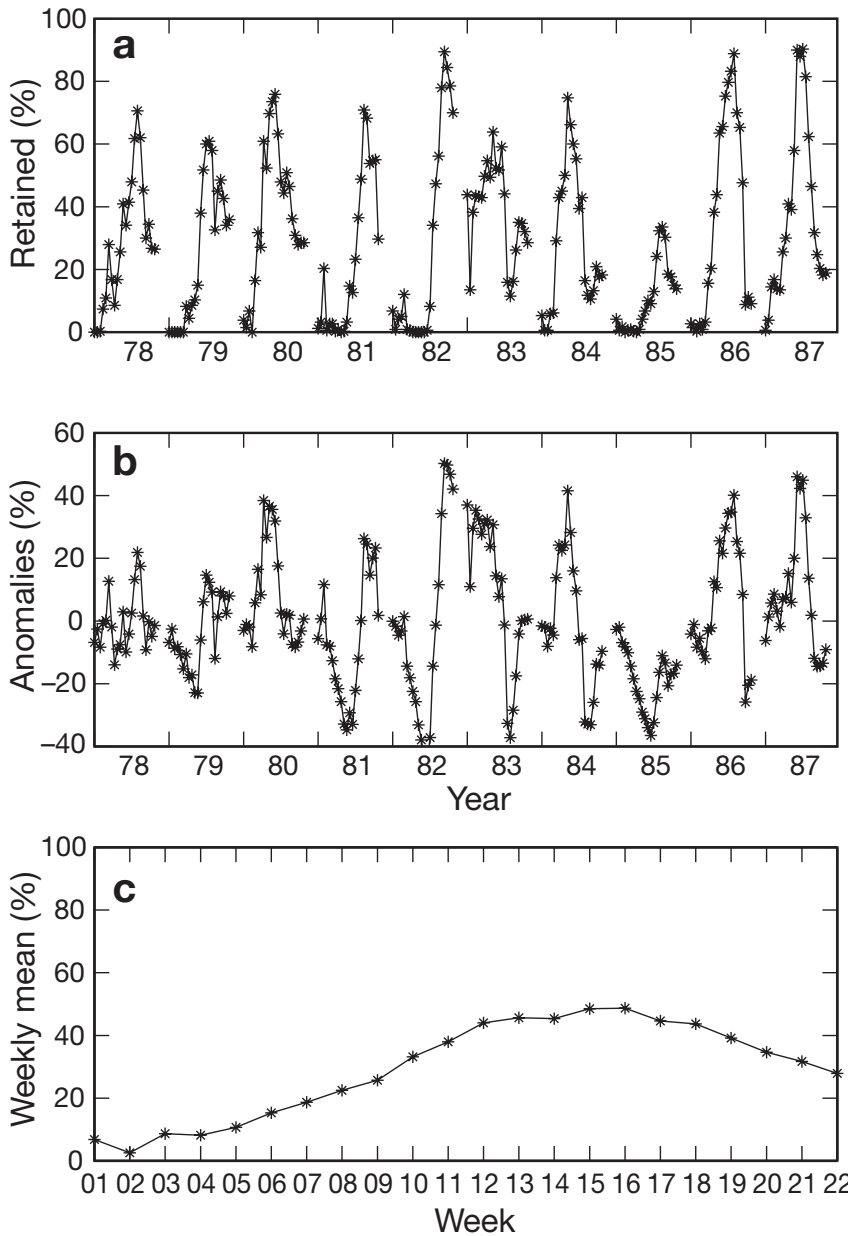

Fig. 6. Particles retained within the $70 \mathrm{~m}$ isobath $8 \mathrm{wk}$ after release from the Northeast Peak (NEP2) at 0 to $10 \mathrm{~m}$, starting every week from the first week of January (Week 1) to the last week of May (Week 22), 1978 to 1987 (a). The weekly mean retention over the time series (c) and the retention anomalies (b), with respect to the weekly mean retention, are shown. GB70: Georges Bank $70 \mathrm{~m}$

occurred at 0 to $10 \mathrm{~m}$ after $4 \mathrm{wk}$. Again, annual retention could vary greatly from the mean. In 1985, retention appeared to be more consistent than in other years. Retention was very low during May 1982.

\section{Scaled aggregate Georges Bank (70 m,} based on cod; Fig. 9)

Only the years 1979 to 1987 were simulated because data on eggs were not available for 1977-1978. There was always more retention for the scaled AGB than for each individual spawning site. For 0 to $10 \mathrm{~m}$ releases, there was low retention $(10 \%)$ during winter, but higher $(40 \%)$ in spring. At $30 \mathrm{~m}$, there was
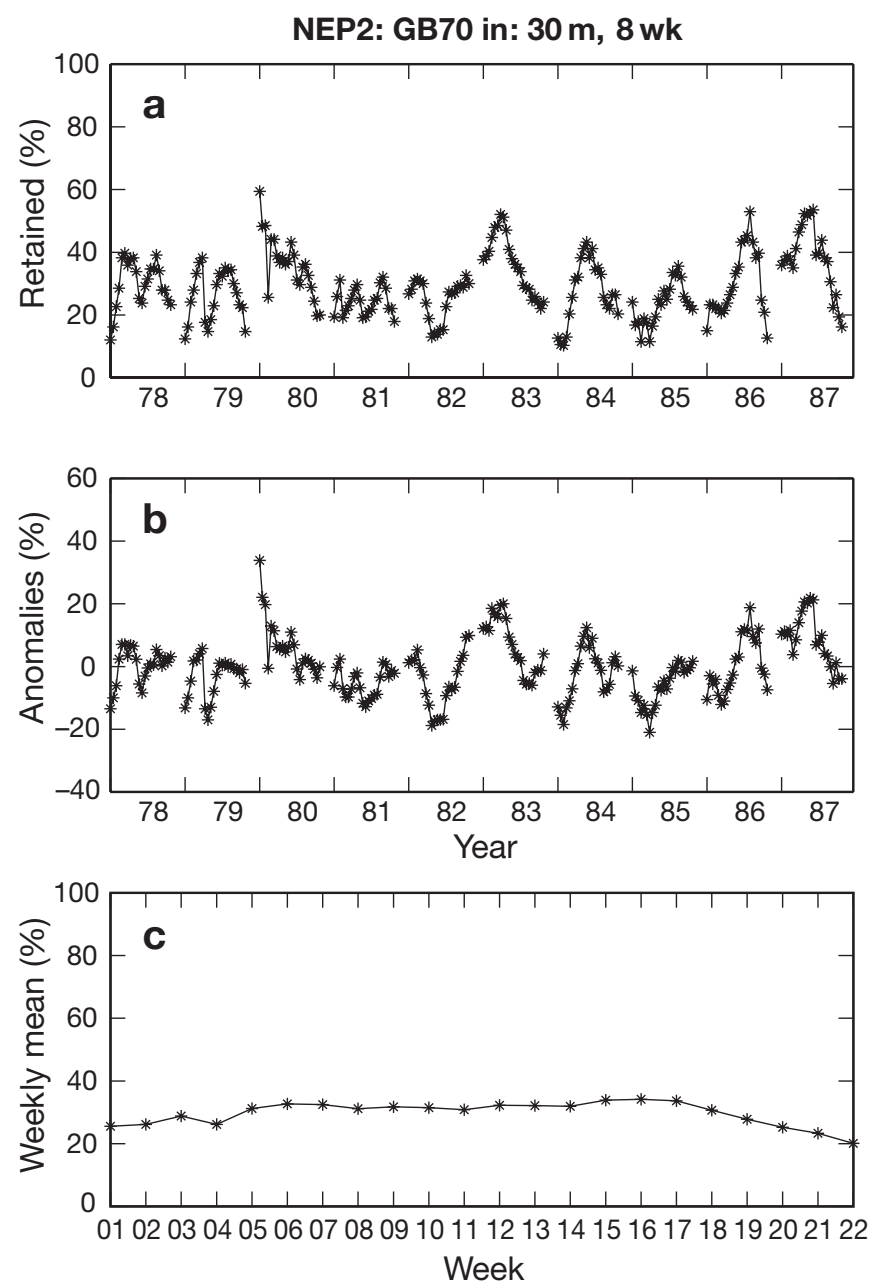

Fig. 7. Particles retained within the $70 \mathrm{~m}$ isobath $8 \mathrm{wk}$ after release from the Northeast Peak (NEP2) at $30 \mathrm{~m}$, starting every week from the first week of January (Week 1) to the last week of May (Week 22), 1978 to 1987 (a). The weekly mean retention over the time series (c) and the retention anomalies (b) with respect to the weekly mean retention, are shown. GB70: Georges Bank $70 \mathrm{~m}$

more uniform retention (20 to $30 \%$ ) during winter/ spring. Retention was always more variable during winter than spring, and more so at the surface $(0$ to $10 \mathrm{~m}$ ) than at $30 \mathrm{~m}$ depth. The NEP2 usually had higher retention than the WGB, and slightly higher retention at 4 than at $8 \mathrm{wk}$. The WGB releases could contribute significantly to retention, especially at the surface $(0$ to $10 \mathrm{~m})$ during the winter period, when there was high wind loss of particles from the NEP2. The most notable pattern in the scaled AGB series was the more consistent surface retention (ca. 30\%) throughout the winter/spring for the years 1979, 1983 to 1986 , and especially for 1985 , where spawning was split between the NEP2 and WGB. Those years in which spawning was predominantly on the NEP2 

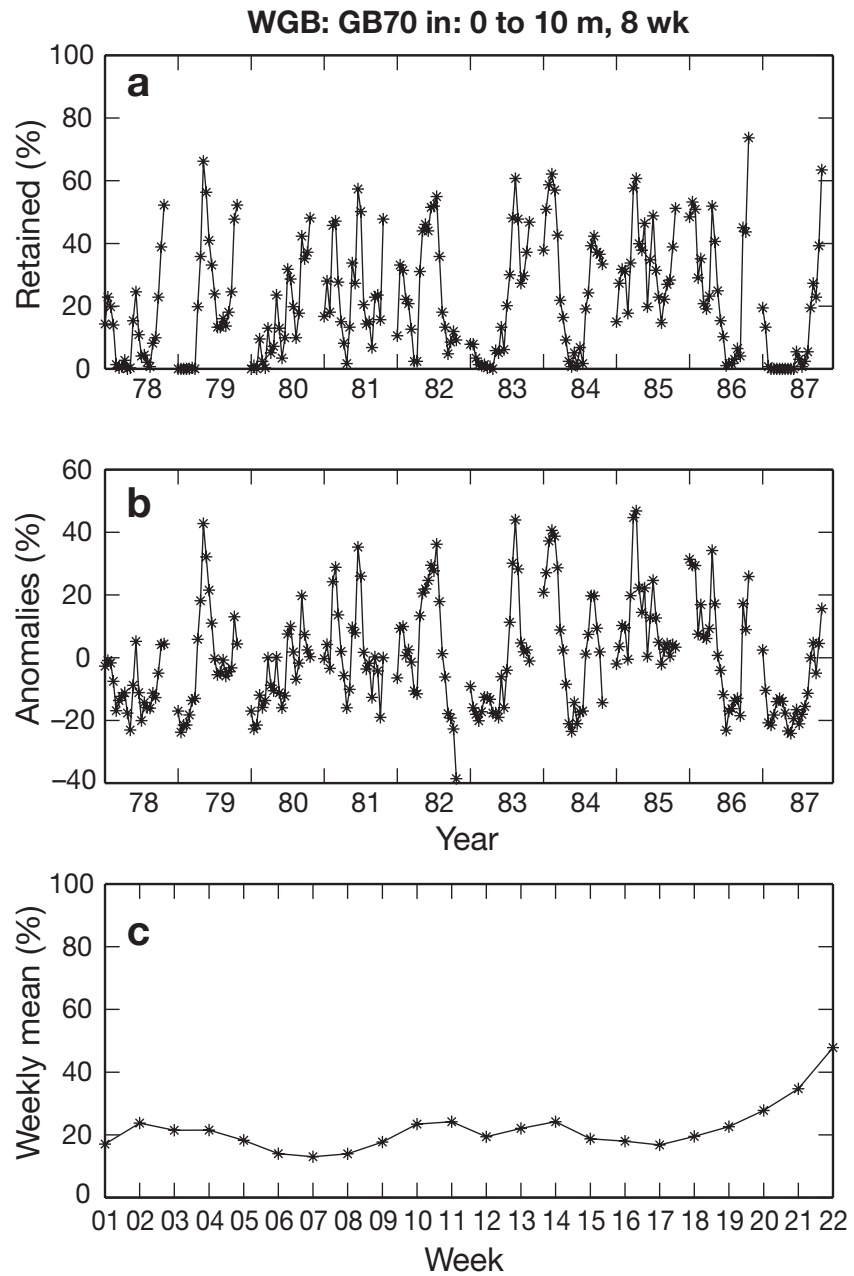

Fig. 8. Particles retained within the $70 \mathrm{~m}$ isobath $8 \mathrm{wk}$ after release from western Georges Bank (WGB) at 0 to $10 \mathrm{~m}$, starting every week from first week of January (Week 1) to the last week of May (Week 22), 1978 to 1987 (a). The weekly mean retention over the time series (c) and the retention anomalies (b), with respect to the weekly mean retention, are shown. GB70: Georges Bank 70 m

(1980, 1981, 1982, and 1987) all had greater variability, with extreme highs and lows in retention. For these years, a peak in retention occurred between March and April.

\section{0-group survival in relation to timing of spawning/hatching}

The stratified mean numbers per tow of 0-group cod and haddock collected in fall groundfish surveys were generally correlated (cod: $r=0.3, N S$; haddock: $r=0.7$, $\mathrm{p}<0.05$ ) with size of the Age 1 year class during the MARMAP years 1977 to 1987, even though the groundfish surveys were not designed to adequately sample the 0-group fish. Despite considerable variabil-
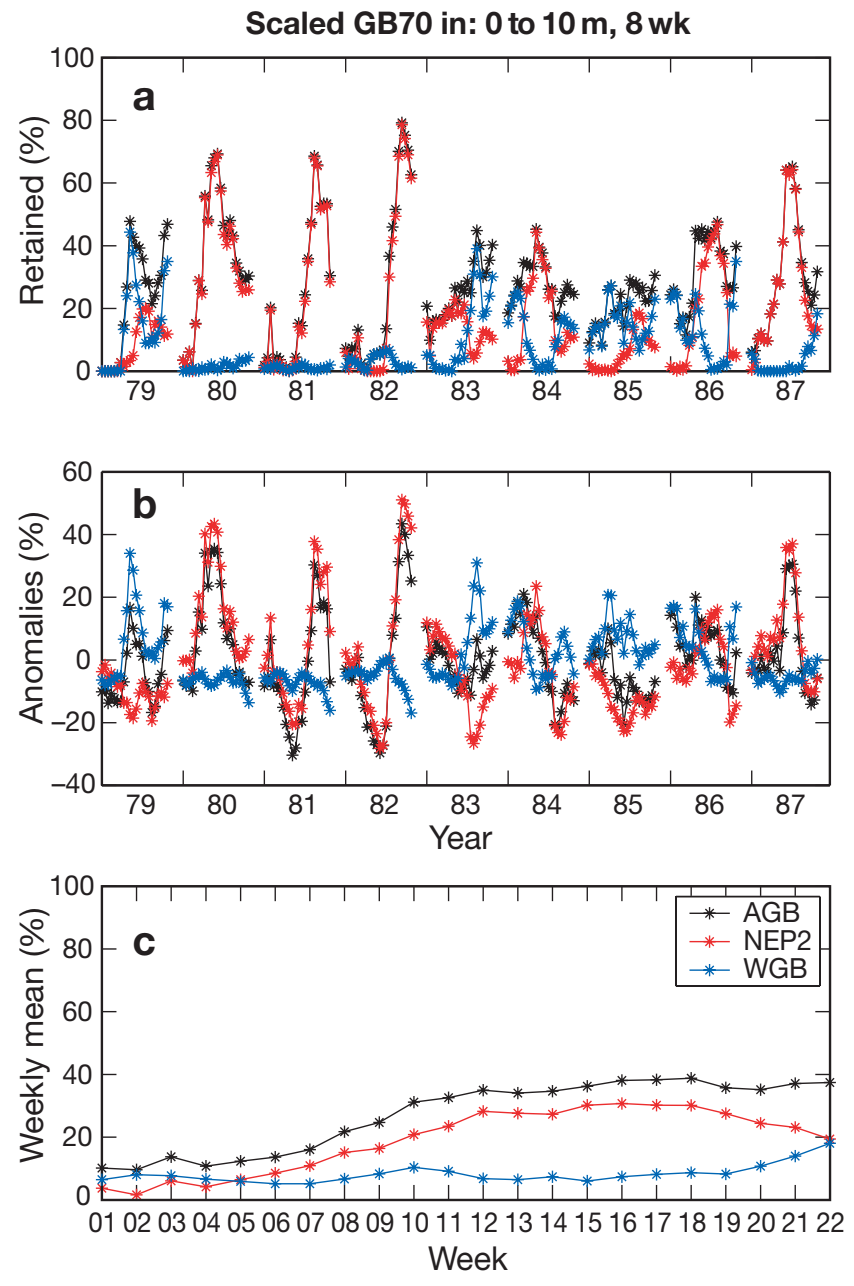

Fig. 9. Particles retained within the $70 \mathrm{~m}$ isobath $8 \mathrm{wk}$ after a scaled release from the Northeast Peak (NEP2) and western Georges Bank (WGB) at 0 to $10 \mathrm{~m}$, starting every week from the first week of January (Week 1) to the last week of May (Week 22), 1979 to 1987 (a). The retention data for each release site was weighted by an estimate of the relative proportion of cod eggs spawned on eastern (NEP2) and western (WGB) parts of the bank. A total retention index AGB (aggregate Georges Bank) combines NEP2 and WGB. The weekly mean retention over the time series (c) and the retention anomalies (b), with respect to the weekly mean retention, are shown. GB70: Georges Bank $70 \mathrm{~m}$

ity in the correlations, the length-frequency distribution of the 0-group survivors, back-calculated with a growth curve to estimate their hatching dates, could then be compared with the hatching density derived from the egg survey data to see in which period of the spawning/hatching curve the survivors may have originated. The scaled AGB, based on the percent of surface to $10 \mathrm{~m}$ particles retained within the $70 \mathrm{~m}$ isobath after $8 \mathrm{wk}$, is superimposed on the spawning/hatching curves for each year class of cod in Fig. 10, and the eastern (NEP2) retention index for haddock year classes in Fig. 11. 

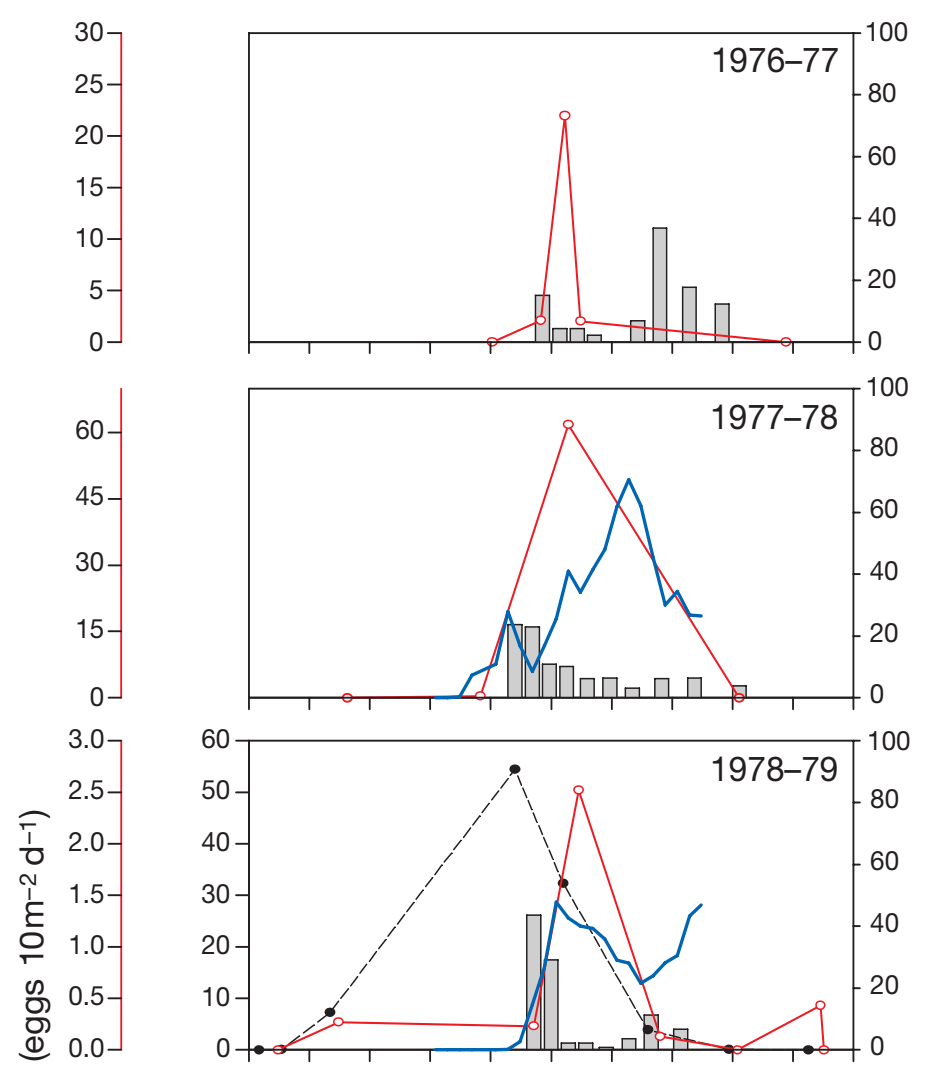

(1) 0.0

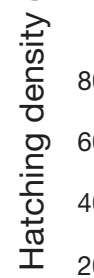

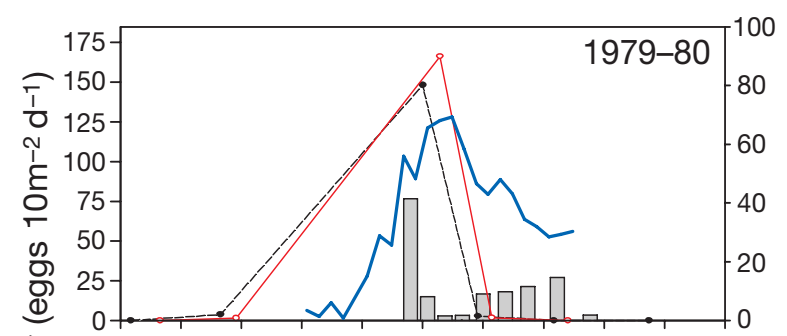

${ }^{107}$



$6-$

$4-$

$2-$

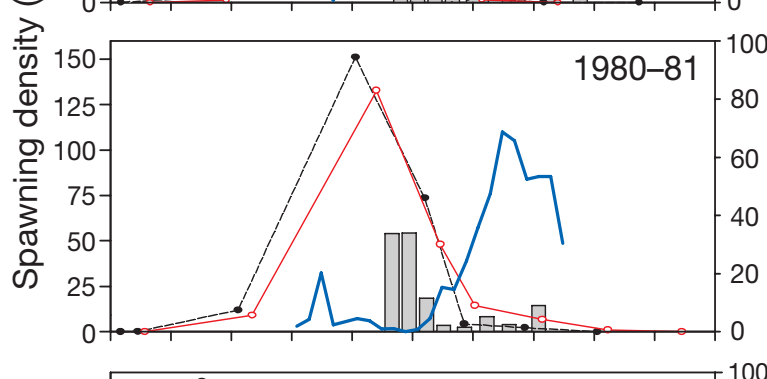

1.0

0.8

0.6

$0.2-$

0.0

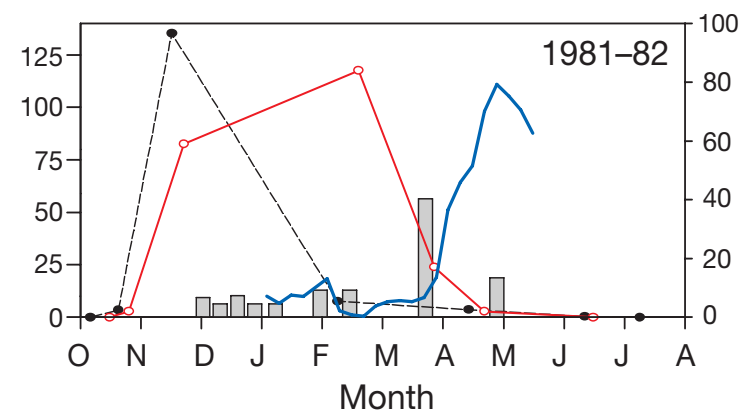

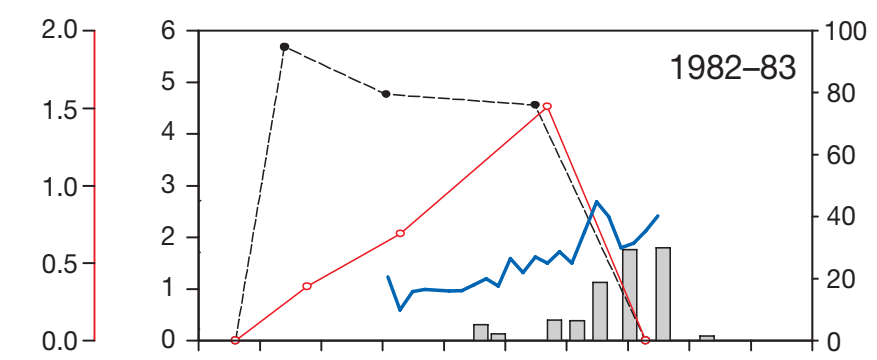

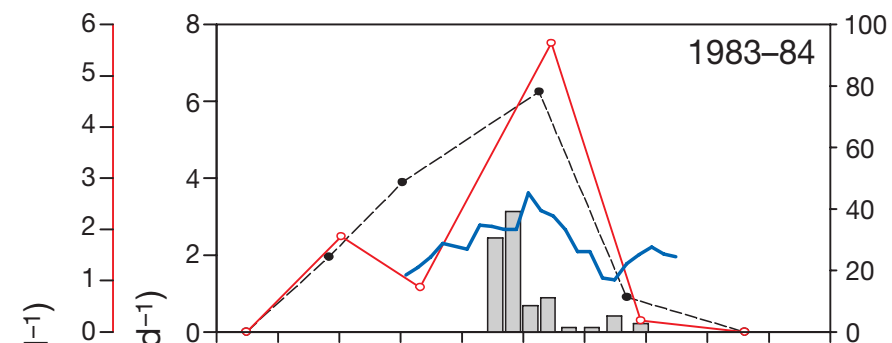

क 0

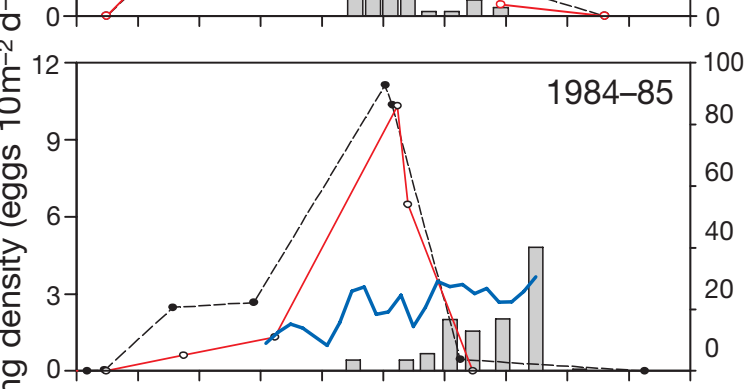

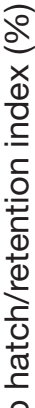

0

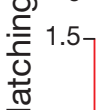

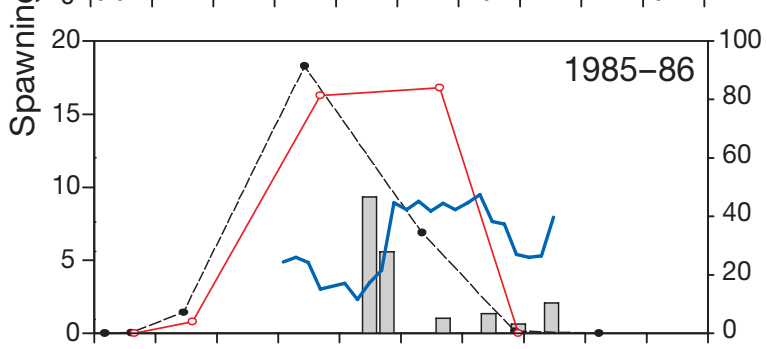

0.0

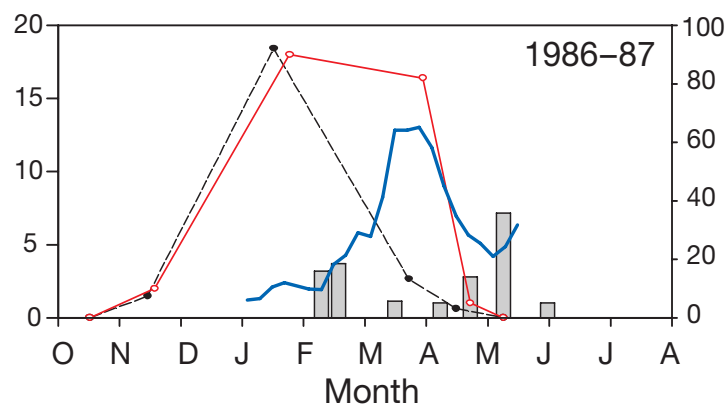

COD 1977 to 1987

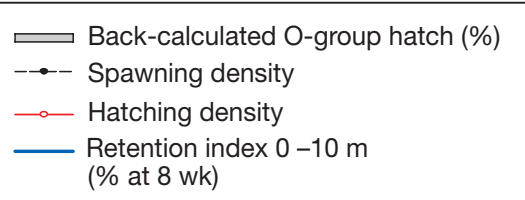

Fig. 10. Comparison of cod back-calculated 0-group hatching dates, egg-derived hatching and spawning dates, and a retention index during the MARMAP period 1977 to 1987 . The retention index is the percent of particles retained within the $70 \mathrm{~m}$ isobath after a weekly scaled release from the scaled aggregate Georges Bank spawning grids. No data on eggs were available for the 1976-77 and 1977-78 seasons.

Hatching density for these 2 yr was derived from larval data. No flow field data were available for the 1976-77 season 

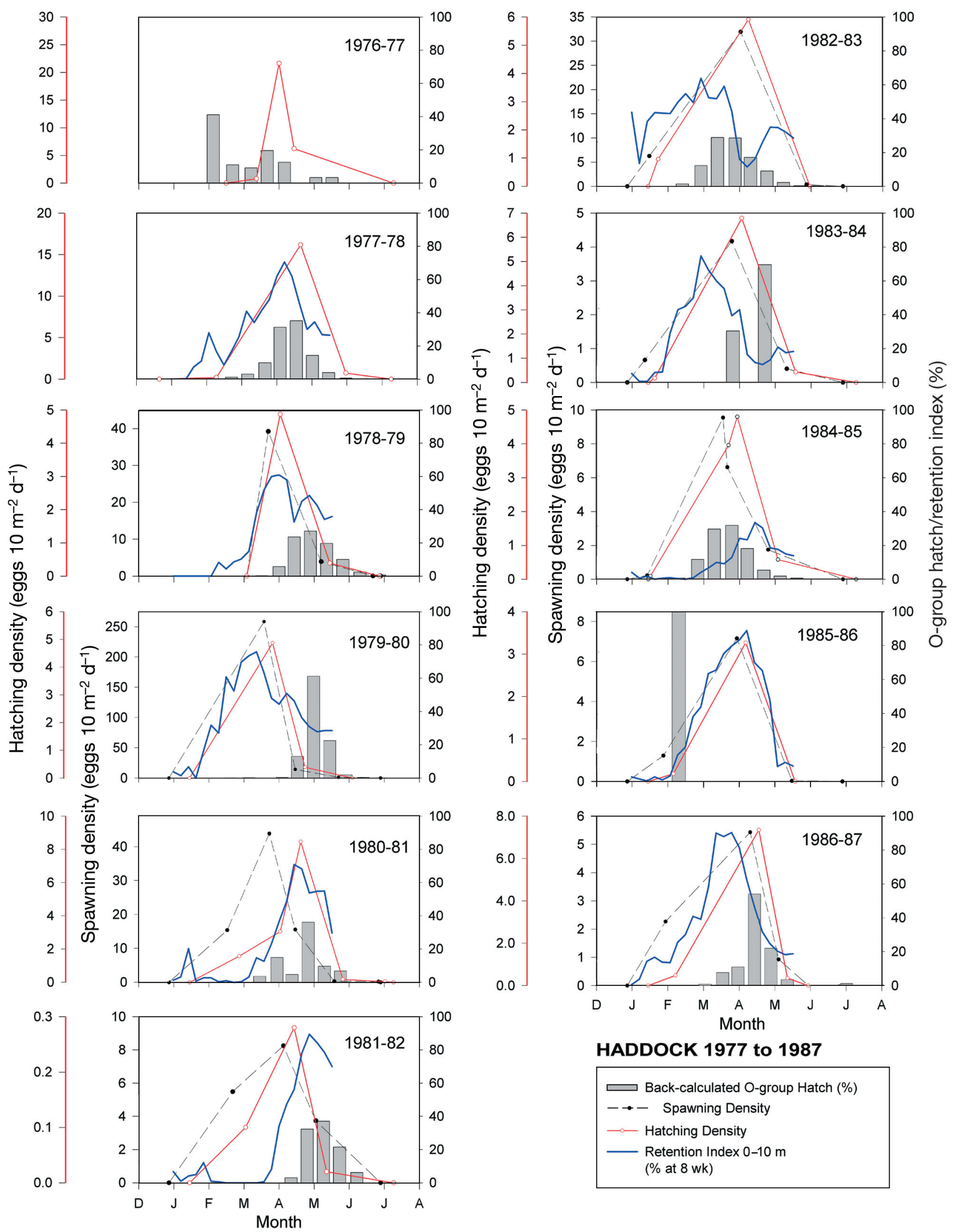

HADDOCK 1977 to 1987

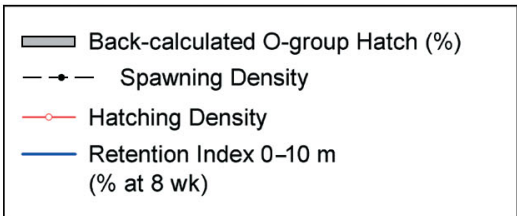

Fig. 11. Comparison of haddock back-calculated 0-group hatching dates, egg-derived hatching and spawning dates, and a retention index during the MARMAP period 1977 to 1987 . The retention index is the percent of particles retained within the $70 \mathrm{~m}$ isobath after a weekly scaled release from the eastern (NEP2) spawning grid on Georges Bank. No data on eggs were available for the 1976-77 and 1977-78 seasons. Hatching density for these 2 yr was derived from larval data. No flow field data were available for the $1976-77$ season 
Cod peak spawning occurred in February during the years 1979, 1980, 1981, and 1985, in early March in 1984, and in January during 1986 and 1987 (Fig. 10). The years 1982 and 1983 were unusual in that peak spawning occurred in November, and in 1983 it continued through March. In 1983, most of cod spawning/hatching occurred prior to the increase in retention, to about $40 \%$ during late April to May, although the 0-group hatch date distribution would indicate their origination in late spring. Note that spawning abundance was very low from 1983 through 1987. Egg-derived hatching abundance consistently peaked in March. In 1982, high hatching abundance occurred from November through March, and, for the most recent years, 1986 and 1987, there was a broad peak of abundance from January through March, consistent with the broader spawning period. The hatching peak abundance of the 0-group only coincided with the egg hatching peak abundance for the 1986 season. The hatching peak abundance of the 0-group was later in late April/May for the majority of years (1977, 1981, 1982, 1983, 1985, and 1987). The hatching abundance of 0-group peaked earlier in February than the egghatching peak in 1978, 1979, 1980, and 1984. The 1980 and 1985 year classes of cod had high recruitment at Age 1, and moderately high in 1978, 1983, and 1987. The lowest year classes of recruitment were 1982 and 1984. Thus, there appears to be an even split between the time of spawning/hatching and the years of high and low recruitment. Note that the larval-derived hatching abundance for the 1978 season was as high as that for $1980,33 \times 10^{12}$, the highest estimated in the 11 yr time series (Table 1).

Favorable environmental effects for the high recruitment of 1980 cod may have occurred prior to April, since most spawning (90\%) was from eastern Georges Bank and peak retention coincided with peak spawning/hatching in March (Fig. 10). There was a $7 \mathrm{wk}$ period from late February into April when retention was near $70 \%$ at the surface and about $35 \%$ at $30 \mathrm{~m}$ depth. 0-group survivors also appeared to originate from March through May. An examination of the survey distributions showed by May that the larger size classes of larvae had their highest concentrations distributed across the shoals, well centered for maximum retention.

Peak spawning for haddock consistently occurred between mid-March and early April, whereas peak hatching generally occurred later, within 2 to $3 \mathrm{wk}$ in April (Fig. 11). The greatest period of time between the peak of spawning and hatching was observed during the 1981 season. The back-calculated 0-group hatch dates of haddock fell within the bounds of the hatching distributions derived from the egg survey data; however, there was considerable interannual variability in the hatching date-frequency distributions. In 5 of the years $(1978,1981,1983,1985,1987)$ the 0 -group hatching curves were centered on the egg-derived hatching curves. In 4 of the years $(1979,1980,1982,1984)$, the 0 -group hatching curves were later, peaking in May, and, in 2 of the years $(1977,1986)$, the 0-group hatching curves were shifted earlier to February. Years of high (1978) and moderate (1983, 1985, and 1987) recruitment at Age 1 originated from peak hatching in April. Haddock peak spawning/hatching occurred in mid-March to mid-April 1983, similar to the 0-group hatch date distribution; however, the retention index was relatively high, $60 \%$, only during the first half of the spawning/hatching season, abruptly decreasing in early April.

\section{Larval growth based on spring temperatures}

Monthly mean temperatures from March to June were very similar for all 5 subareas (Fig. 12), so only the SGB subarea is summarized here, where most of the larvae resided in the spring. March and April had a similarly low mean temperature of 4 to $5^{\circ} \mathrm{C}$; warming began in May, and significantly so in June. Monthly mean temperatures indicate a 1 to $2^{\circ} \mathrm{C}$ warming trend over the 1978 to 1987 time series. March to April of 1983 was significantly warmer $\left(2^{\circ} \mathrm{C}\right)$ than the longterm average for the same period. June of 1981 and 1979 also appeared warmer than average.

Growth trends were similar in all 5 subareas, so only the SGB subarea is shown. Larval populations tended to be centered along the southern flank in April to May. Also, the time periods used for growth averages

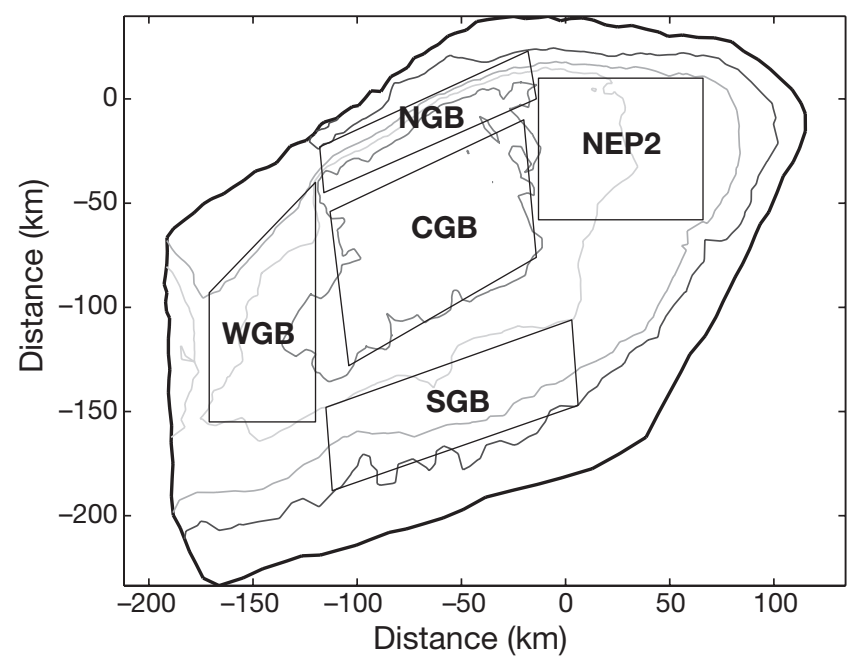

Fig. 12. Five subarea polygons used for calculating temperature time series: Northeast Peak 2 (NEP2), northern Georges Bank (NGB), western Georges Bank (WGB), central Georges Bank (CGB), and southern Georges Bank (SGB) 
$(1,2$, and 4 wk) showed similar trends. Only the $1 \mathrm{wk}$ growth plots are shown in Figs. 13 \& 14, because they focus on the first week post-hatching of larvae and also provide more definition of the growth curves. The Buckley et al. (2004) growth formulation, which was developed for larvae caught in May, readily shows growth optima with the warmer temperatures in May, but does not apply well to the lower temperatures generally found earlier in the spring. The Campana \& Hurley (1989) formulation generally produces a flatter growth curve, but gives values at the lower temperatures. Comparing larval cod and haddock by the Buckley et al. (2004) formulation, the growth optima for both species were similar but more dome-shaped for haddock, since it is more temperature sensitive. Using the Campana \& Hurley (1989) formulation, there was no apparent dome in the growth optima, but growth of haddock was half that of cod.

The trend in growth shows that optimal conditions occurred later in the spring from 1978 to 1982, when waters were generally colder. In 1983 to 1987, optimal growth was earlier in the spring, when waters were generally warmer. Comparing the 5 and $30 \mathrm{~m}$ depth growth curves, optimum growth appeared later in the season (April at $5 \mathrm{~m}$ versus May at $30 \mathrm{~m}$ ) due to the surface waters in April warming above the temperature optimum $\left(7^{\circ} \mathrm{C}\right)$ for growth in May, but still being near the optimum at $30 \mathrm{~m}$ depth. Spring 1978 had one of the latest seasonal growth optima at $30 \mathrm{~m}$. Growth based on water temperature can be quite variable across Georges Bank. For example, on 20 May 1978, during a cold year, high growth was indicated (plots not showed here) for the central part of the bank and low growth around the perimeter. Whereas on 20 May 1984, during a warm year when temperatures on the shoals exceeded the optimum, low growth was estimated for the central bank and high growth around the perimeter.

\section{DISCUSSION}

Declines in the northwest Atlantic groundfish stocks over the last $50 \mathrm{yr}$, and especially since the 1990s, have been attributed primarily to recruitment over-fishing (Myers et al. 1996). There have been many attempts to correlate recruitment with environmental variability, but the correlations were often low, although temperature is known to influence all aspects of life history. Planque \& Frédou (1999), in a meta-analysis of recruitment data from 9 stocks around the North Atlantic, found that cold-water stocks were positively correlated with temperature and warm-water stocks negatively, and stocks at intermediate temperatures, e.g. on Georges Bank, showed no relationship. Global warming would lead to a northward shift in populations. Colder temperatures have been implicated in the decline of the northern cod stock off southern Labrador and northeastern Newfoundland in the 1990s by contributing to slower growth, increased mortality of eggs, and a southward displacement of the population (Drinkwater 2002). Other long-term ecosystem changes are thought to be limiting stock recovery, such as increased stratification that favors the pelagic taxa herring and mackerel (Choi et al. 2004).

Moderate synchrony was found between cod and haddock recruitment within regions across the North Atlantic by Fogarty et al. (2001), suggesting a common

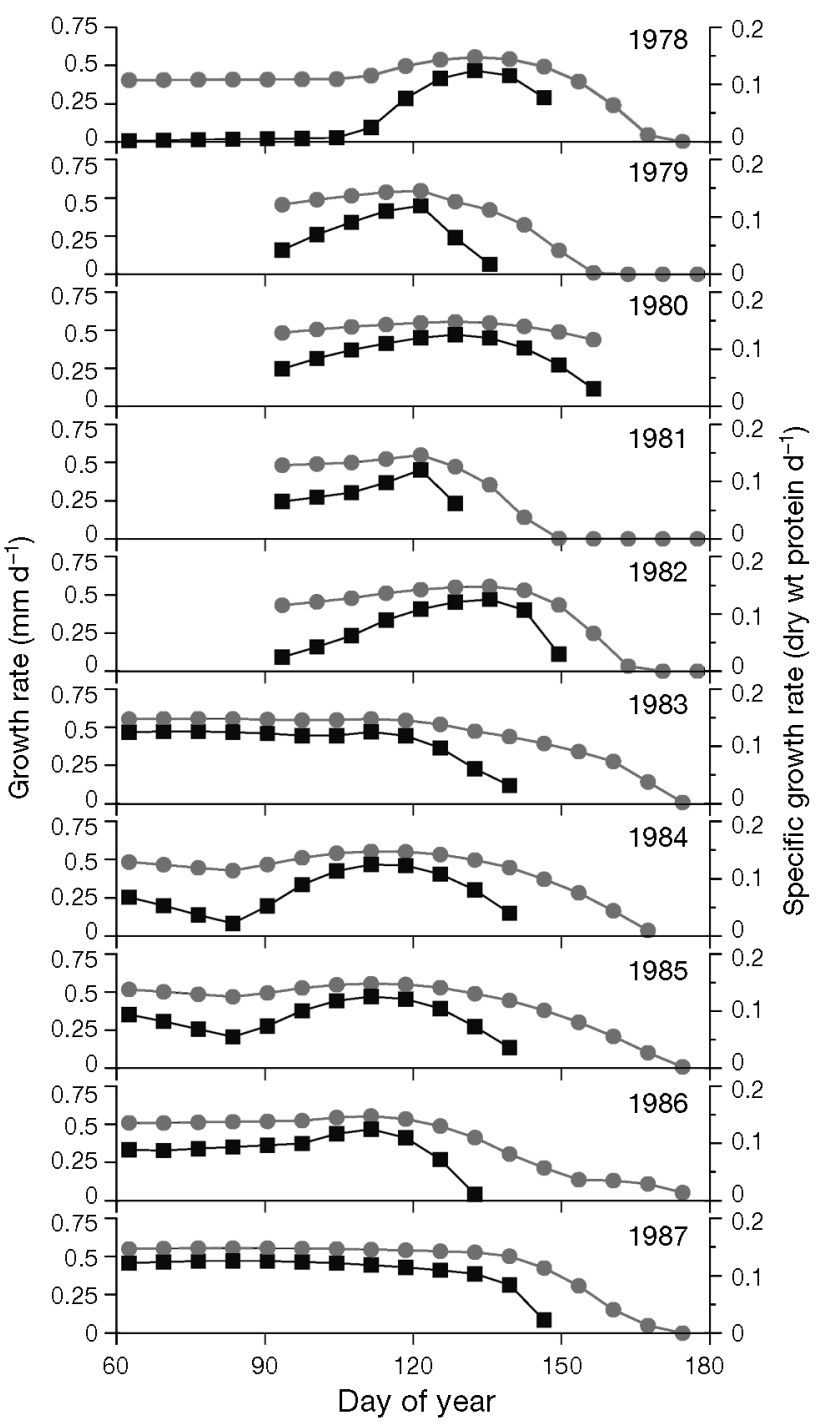

Fig. 13. Weekly mean larval cod growth rate using 2 growth models incorporating a temperature term for the southern Georges Bank subarea at 5 m, March to June 1978 to 1987. : Campana \& Hurley (1989) growth rate estimates $\left(\mathrm{mm} \mathrm{d}^{-1}\right)$; 口: Buckley et al. (2004) specific growth rate values (dry wt protein content $\mathrm{d}^{-1}$ ) 
environmental effect. Recently, Brodziak et al. (2001) evaluated several stock-recruitment models for 11 groundfish stocks off New England (including Georges Bank cod and haddock), in an effort to determine the relative importance of density-dependent versus density-independent processes. While providing strong evidence that spawning stock size affected the dynamics of Georges Bank cod and haddock, model uncertainty was substantial and environmental forcing was likely in both cases.

Myers \& Cadigan (1993), in an analysis of 17 species of North Atlantic demersal fish, demonstrated the importance of density-dependent mortality in the juve-

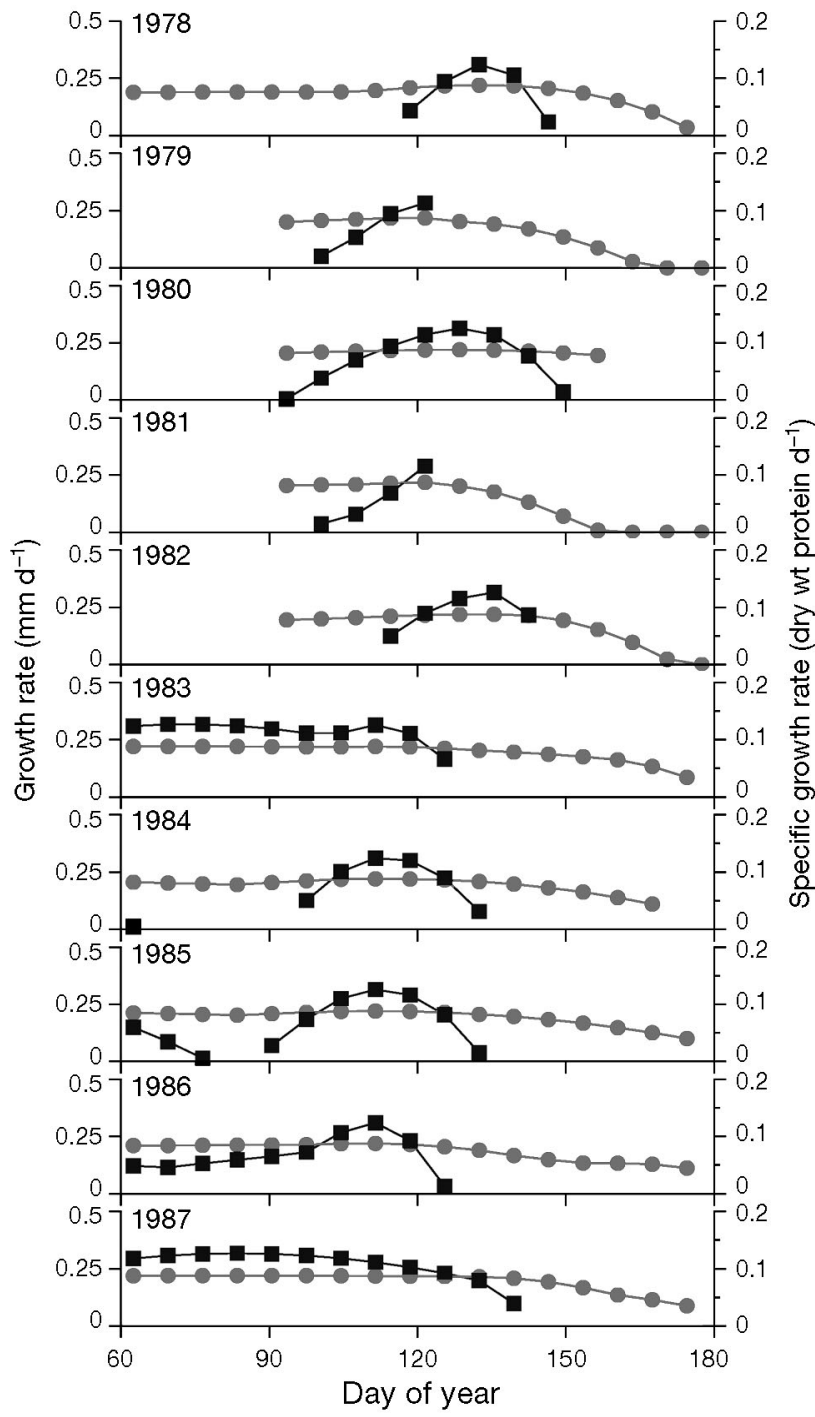

Fig. 14. Weekly mean larval haddock growth rate using 2 growth models incorporating a temperature term for the southern Georges Bank subarea at 5 m, March to June 1978 to 1987. C: Campana \& Hurley (1989) growth rate estimates $\left(\mathrm{mm} \mathrm{d}^{-1}\right)$; $\mathbf{\square}$ : Buckley et al. (2004) specific growth rate values (dry wt protein content $\mathrm{d}^{-1}$ ) nile stage, more so for cod than haddock, the exception being Georges Bank cod, which shows no evidence of density-dependent mortality because the population is so small. Nevertheless, their analyses suggested that the source of variability in relative year-class strength was determined in the larval or early juvenile stages. Many different factors can determine the size of a cohort, but conditions favorable for a large year class would include: (1) average to high spawning biomass with older age classes to insure high egg survival; (2) high larval growth, which is a function of prey abundance and optimal temperature; (3) retention within the stock region, Georges Bank in this case; and (4) no significant mortality events due to environmental extremes of temperature, transport, predation, disease, etc. High recruitment is more likely at higher spawning-stock abundance, with many repeat spawners, since first-time spawners have poor fecundity and low egg/larval survival (Trippel 1998, Wigley 1999, Rideout et al. 2005).

On Georges Bank, the 1980 and 1985 year classes of cod were the most abundant, followed by the 1983 , 1987, and 1978 cohorts. Haddock stocks, historically, only have 3 to 4 high recruitment years over a $20 \mathrm{yr}$ time series. The extremely large 1963 year class was followed by a series of very weak year classes, coinciding with the collapse of the stock in the late 1960s. The 1975 and 1978 year classes had relatively large recruitment, followed by years of depressed spawning stock biomass. The 1983, 1985, 1987, and 1992 year classes were large relative to recent recruitment, but only reached $1 / 3$ of the average recruitment observed from 1935 to 1960.

Over the investigated period, Georges Bank cod and haddock females matured at a younger age as the stocks declined, except for Age 2 haddock (O'Brien 1999, Wigley 1999). Wigley (1999) estimated that the exclusion of the first-time spawners in haddock improved the stock-recruitment relationship by $39 \%$. However, these parameters alone did not predict a large year class. O'Brien et al. (2003) found a significant correlation between egg abundance and spawning stock biomass for Georges Bank cod. Variability in egg survival could be explained partially by the age diversity of repeat spawners, bottom temperature, and the spatial distribution of the eggs.

Cod spawning and hatching abundances were generally higher earlier in the time series, 1977 to 1982, but no clear pattern was evident in the estimates of egg or larval mortality rates. Mortality rates of cod eggs and larvae on Georges Bank were estimated to be $10 \% \mathrm{~d}^{-1}$ on average. Morse (1989) estimated an average mortality of $4 \% \mathrm{~d}^{-1}$ during the $100 \mathrm{~d}$ period between hatching $(4 \mathrm{~mm})$ and $20 \mathrm{~mm}$ from the same 1977 to 1987 time series. Post-larval $(20$ to $50 \mathrm{~mm}$ ) or pelagic juvenile 
mortality in cod is comparable to that experienced in the egg and larval stages (Serchuck et al. 1994). In 1986 and 1987, when we had direct estimates of post-larval cod abundance from June surveys, the egg and larval mortality rates were 6.8 and $5.6 \% \mathrm{~d}^{-1}$, respectively. Post-larval mortality from about mid-June until Age 1 was $6.2 \% \mathrm{~d}^{-1}$ in 1986 and $6.8 \% \mathrm{~d}^{-1}$ in 1987 . Haddock spawning was presumably highest in the first 4 yr, 1977 to 1980, and exceptionally high for the 1980 year class. Egg and larval mortality rates ranged similarly to those of cod, with no apparent correlations. The highest larval mortality rate of $30 \% \mathrm{~d}^{-1}$ occurred with the very large hatching abundance estimated for the 1978 year class. However, these estimates are questionable, since survey coverage for haddock was essentially limited to a single cruise in May.

The inshore Gulf of Maine cod stock appears to be relatively distinct from the offshore stocks on the banks of the Scotian Shelf and Georges Bank. Although there is some mixing of the Gulf of Maine and Georges Bank stocks, their life-history parameters, growth, and maturity are basically different (Serchuck et al. 1994, O'Brien 1999). Part of the difference in growth between stocks may be attributed to genetic variations. General conclusions by Imsland \& Jónsdóttir (2003) from basin-scale genetic studies suggest that distinct subpopulations occur between most inshore and offshore areas, and among offshore areas themselves, and that the likelihood of inshore spawning stock contributing to offshore recovery is low. Recent genetic studies by Lage et al. (2004) suggest that Nantucket Shoals cod are distinct from Georges Bank cod. Whereas Lage et al. (2004) did not find any significant genetic differences between Georges Bank and Browns Bank, Ruzzante et al. (1998) did. The degree of stock separation may be related to the isolation of spawning locations and times, and different circulation patterns. On Georges Bank, a clockwise gyre circulation pattern tends to retain and isolate the eggs and larvae spawned there (Smith \& Morse 1985, Lough \& Bolz 1989, Werner et al. 1993, Lough \& Manning 2001). Model simulations by Page et al. (1998) suggest that cod spawning occurs in areas and at times of the year that have the longest residence times (>35 d). However, advective losses can occur sporadically off the northeast peak and southern flank of Georges Bank (Lough et al. 1994). While significant numbers of larvae can be advected across the Great South Channel to Nantucket Shoals, the southwest residual flow in the Nantucket shoals area would tend to keep the early life stages from returning to Georges Bank. However, based on biophysical modeling of haddock by Brickman (2003), there is a high probability of significant crossover events from Browns Bank to Georges Bank by 2 pathways, directly across the
Northeast Channel and from the Gulf of Maine. While crossover events are episodic in nature (Smith et al. 2003), the study indicates that Browns Bank can be a significant source of larvae for Georges Bank cod stocks, and similarly, the Western Bank of the Scotian Shelf can be an upstream source for larvae found on Browns Bank.

Large differences in the winter phytoplankton abundance in the Gulf of Maine can influence the zooplankton abundance and productivity ultimately reaching Georges Bank (Durbin et al. 2003). The dominant coldwater copepods in the spring are Calanus finmarchicus, Pseudocalanus spp. and Oithona spp., and the life stages of Pseudocalanus, especially, are the primary prey for cod and haddock larvae (Kane 1984, Lough \& Mountain 1996). Seed populations for these species are advected onto Georges Bank from various sources in the Gulf of Maine and on the Scotian Shelf (Durbin et al. 1997). The abundance of Calanus populations is largely determined by the abundance of adult females returning to the surface during early winter from the deep basins of the Gulf of Maine, rather than advective events that can determine the abundance of Pseudocalanus and Oithona (McGillicuddy \& Bucklin 2002). An unusual phytoplankton bloom occurred in the winter of 1999 in the Gulf of Maine, as well as on the Scotian Shelf (Platt et al. 2003). The initial spread of low-salinity Scotian Shelf water across the eastern Gulf of Maine in early 1999 apparently resulted in a shallow, surface, mixed layer that allowed a bloom to develop. The influx of Scotian Shelf water also carried zooplankton into the Gulf of Maine not normally abundant. The earlier winter bloom also may have allowed an additional generation of Calanus prior to the normal March to April spring bloom. Zooplankton was an order of magnitude more abundant in 1999 than in 2000. The high abundance of zooplankton in the Gulf of Maine during 1999 was also observed on Georges Bank, and Pseudocalanus abundance was most correlated with larval cod and haddock growth (L. J. Buckley \& E. G. Durbin unpubl. data). The earlier development of zooplankton populations on Georges Bank would lead to enhanced survival for larvae hatched earlier in the season (Lapolla \& Buckley 2005). While haddock recruitment on Georges Bank was only moderately high from the 1999 year class, an exceptionally abundant year class occurred in 1999 on the Scotian Shelf (Head et al. 2005). High survival to the settled 0-group fish on the eastern Scotian Shelf was attributed to spawning earlier than usual when the larvae encountered an early spring bloom and peak production in Calanus finmarchicus in late February. However, their study did not determine whether the principal prey of the larvae were in fact the various stages of C. finmarchicus. 
Given the preceding background, can the MARMAP time series be viewed from a different perspective? The large year class of haddock in 1978 originated from a modest spawning stock biomass, but apparently had very high Age 1 recruitment survival. From the limited survey data, the estimated abundance of larvae at hatching was the highest in the time series by several orders of magnitude. The 0-group hatching distribution was centered on April, which coincided with the peak hatching abundance curve and high retention index of 60 to $70 \%$. This year also had the latest seasonal larval growth optima in the time series, extending through May at $30 \mathrm{~m}$ depth. Plankton copepod abundance was relatively high in May 1978 (Kane 1993), promoting greater larval growth at warmer temperatures, when not food limited. And, the later they occur in the spring, the more daylight hours are available for feeding. As seasonal stratification intensifies in late May to June, the baroclinic flow strengthens, which is important for recirculation at the western end of the bank, and it has the added benefit of aggregating larvae and copepod prey near surface pycnoclines, which can result in increased feeding (Lough \& Mountain 1996) and growth (Buckley et al. 2004). For haddock, which can grow more rapidly than cod, the 1978 season appeared to provide ideal conditions for high survival. Lapolla \& Buckley (2005) reported on a more recent strong year class of haddock, 1998, which appeared to have similar conditions, in that individuals hatched in the later half of the spawning curve had enhanced survival.

The high mortality rates in 1982 for both cod and haddock were consistent with the high wind event loss off the shelf/slope front as reported by Lough et al. (1994). Retention was very low through the winter until late April/May, whereas peak spawning had already passed.

In 1984, loss of larvae off the southern flank in April to May coincided with low retention indices for haddock and also low plankton volumes (Kane 1993). Haddock peak spawning/hatching in April missed the highest retention, which occurred in March; the early larvae occurred at a time when retention was at its lowest. In contrast, cod spawning/hatching occurred at peak retention in March and could also potentially have had a higher retention, since spawning was split between the eastern and western Georges Bank, unlike haddock, which spawned primarily on the eastern Georges Bank. Still, the very low plankton biomass observed in the spring of 1984 may have resulted in poor growth and survival for both species.

Recruitment for the 1985 year class of cod was as high as that for the 1980 year class. Recruitment survival was higher in 1985 than in 1980, and could be attributed in part to greater retention as previously shown in simulations by Lough et al. (1994). In 1985, cod spawning was split equally between the eastern and western Georges Bank, whereas, in 1980, spawning was primarily on the eastern Georges Bank. The back-calculated hatch dates of the 0-group appeared to have originated from the April to May period. While the retention index was modest in 1985, it was fairly consistent ( $20 \%)$ from mid-February to June using the aggregate spawning area simulation. Retention peaked in April 1985, when haddock larvae were in the early larval period. The hatch date distribution of the 0-group resembled the spawning/hatching curves, peaking in March to April. Environmental conditions appeared to be favorable for high recruitment survival from a relatively small haddock spawning stock.

In 1987, both cod and haddock had good year classes that can be attributed in part to high retention on the bank. Cod peak retention in March coincided with high abundance of recently hatched larvae, and by April their distributions showed them to be broadly distributed across the CGB, where they would most likely be retained. For haddock, the retention index was very high (80 to $90 \%$ ) in March and then declined sharply in April to a low of $20 \%$ when the spawning/hatching curves peaked. The back-calculated hatch dates would indicate that most 0-group fish originated from the April period, coincident with early larval peak abundance. Polacheck et al. (1992) documented the unusual westward advection of shelf water and haddock larvae during April and May 1987 from Georges Bank to the Mid-Atlantic Bight. There was continuous westward transport of shelf water over the season at a speed of perhaps 12 to $17 \mathrm{~cm} \mathrm{~s}^{-1}$ compared to a mean of 5 to $10 \mathrm{~cm} \mathrm{~s}^{-1}$ for normal years. The center of spawning activity was still on the eastern Georges Bank, but, by April, 35\% of haddock larvae occurred west of Nantucket Shoals; by May, 25\%, and, by June, $57 \%$ had drifted into the Mid-Atlantic Bight. Cod spawning was evident on the eastern Georges Bank in January. By mid-April, cod eggs and larvae were distributed mostly on CGB. By late May, larvae extended across the Great South Channel into Nantucket Shoals. The earlier spawning of cod may have resulted in greater retention of cod larvae due to their settlement prior to the advective event, or due to their central bank location. The relatively large 1987 year class of haddock was attributed by the authors to survivors returning to Georges Bank the following year as juveniles. However, our simulations would indicate that a sufficient part of the haddock population could still have resided in the shoals of Georges Bank to account for the relatively high recruitment. An examination of the survey egg and larval distributions in Polacheck et al. (1992, their Fig. 3) and in the present 
study (Fig. 11) shows the peak abundance of 0-group fish originated in mid-April, when retention was still at $50 \%$; thus, it could be interpreted that a significant part of the larval population may have settled out on the shoals, which would have been unavailable to bongo-net sampling. Also, the stratified mean catch per tow of 1.78 for 0-group haddock from Georges Bank in 1987 (Table 4 in Polacheck et al. 1992) was comparable to that in 1983 (2.24) and in 1985 (7.12); these values were on the same Age 1 recruitment levels as the 1985 and 1983 year classes (Fig. 2).

\section{CONCLUSIONS}

Cod and haddock spawn on continental shelves, where the current systems usually retain some fraction of the pelagic stages to settlement within the domain of the adult populations. Banks are special cases within the shelf ecosystem, where the retention of eggs/ larvae is dependent on the size of the bank, and, for the larger banks, the strength of a semi-enclosed gyre that develops in late spring/summer around the deeper flanks. On Georges Bank, historic spawning grounds are located on the northeastern part, which has the greatest retention on average (Page et al. 1998). Peak spawning of cod generally occurred in February, while haddock peak spawning occurred between midMarch and early April. The relative abundance of eggs spawned on the eastern or western half of Georges Bank was quite variable for cod, whereas haddock spawned predominantly on the eastern side. The interannual variability in retention was estimated for the MARMAP years by a circulation model based on the seasonal mean circulation, wind stress, and upstream boundary forcing. Two spawning regions were considered, NEP2 and WGB, and particles were released in weekly mean flow fields during winter/spring, tracked over 1 to 2 mo and considered retained if they resided within the $70 \mathrm{~m}$ isobath. Model results appeared to capture the major distributional patterns when compared with survey data.

Modeled retention indices from the eastern and western spawning sites indicated that more larvae would be retained on the bank after 1 to 2 mo with combined releases from both sites throughout the winter and spring than from 1 site alone. Retention of particles released from NEP2 was generally low at the surface in the winter due to wind transport loss, but higher in the spring with moderated winds. Particles released at depth $(30 \mathrm{~m})$ had consistently high and uniform retention throughout the winter/spring. Particles released from the western spawning grid generally moved eastward along the northern edge and tended to stay within the shoal region of the bank.
Retention of particles was higher for surface releases than at depth and especially during late May.

While the degree of recruitment success attributed to spawning stock or environmental effects is ambiguous, it appears that the success of the 1978 year class of haddock experienced a set of conditions favorable for early survival and recruitment. These conditions included a high abundance of larvae coinciding with a high retention index, and a late seasonal growth optima in May near the thermocline at a time and place where the increased daylength and abundant prey enhanced larval foraging.

The 1980 and 1985 year classes of cod had similar high recruitment even though egg abundance was an order of magnitude lower in 1985, indicating high recruitment survival. In 1980, the spawning maximum coincided with 2 mo of very high retention, and eggs and larvae were observed to be broadly distributed over the central bank region. In 1985, while the retention index was modest, it was very consistent throughout winter and spring. Significant retention still may have occurred during the 1985 season due to the spawning split between the eastern and western areas, whereas, in 1980, spawning was predominantly on the eastern side.

The 1982 and 1984 year classes of both cod and haddock had the lowest recruitment in the time series, which could be attributed to the low spawning biomass and the substantial loss of eggs and larvae off the bank; furthermore, the low plankton biomass observed would not have provided the best growth conditions for the remaining survivors.

The importance of retention to recruitment during a spawning season depends on the vicissitudes of nature. There are many contributing factors that depend on the timing and location of events for larvae and their prey and predators. Retention can be a major contributing factor in some years, both positive and negative, but in most years it appears to be one of many factors. Of course, when a stock is very low, such as for cod, any increase in retention would appear to be beneficial. Finally, these observations support the view that each year class has its own case history.

Acknowledgements. We thank S. Oakey for helping produce estimates of the temperature fields, circulation, and retention indices, R. Brown and L. O'Brien for providing stock assessment data, and E. Broughton for help with figures. This is contribution 277 of the US GLOBEC program, funded jointly by NOAA and NSF.

\section{LITERATURE CITED}

Berrien P, Sibunka J (1999) Distribution patterns of fish eggs in the U.S. northeast continental shelf ecosystem, 1977-1987. NOAA Tech Rep NMFS 145:1-310 
Bolz GR, Lough RG (1988) Growth through the first six months of Atlantic cod, Gadus morhua, and haddock, Melanogrammus aeglefinus, based on daily otolith increments. Fish Bull 86:223-235

Brickman D (2003) Controls on the distribution of Browns Bank juvenile haddock. Mar Ecol Prog Ser 263:235-246

Brodziak JKT, Overholtz WJ, Rago PJ ( 2001) Does spawning stock affect recruitment of New England groundfish? Can J Fish Aquat Sci 58:306-318

Buckley LJ, Caldarone EM, Lough RG (2004) Optimum temperature and food-limited growth of marine fish larvae. Fish Oceanogr 13:134-140

Butman B, Beardsley RC (1987) Long-term observations on the southern flank of Georges Bank, Part I. Description of the seasonal cycle of currents, temperature, stratification, and wind stress. J Phys Oceanogr 17:367-384

Butman B, Loder JW, Beardsley RC (1987) The seasonal mean circulation: observation and theory. In: Backus RH (ed) Georges Bank. MIT Press, Cambridge, MA, p 125-138

Campana SE, Hurley PCF (1989) An age- and temperaturemediated growth model for cod (Gadus morhua) and haddock (Melanogrammus aeglefinus) larvae in the Gulf of Maine. Can J Fish Aquat Sci 46:603-613

Choi JS, Frank KT, Leggett WC, Drinkwater K (2004) Transition to an alternate state in a continental shelf ecosystem. Can J Fish Aquat Sci 61:505-510

Drinkwater KF (2002) A review of the role of climate variability in the decline of northern cod. Am Fish Soc Symp 32: $113-130$

Durbin EG, Runge JA, Campbell RG, Garrahan PR, Casas MC, Plourde S (1997) Late fall-early winter recruitment of Calanus finmarchicus on Georges Bank. Mar Ecol Prog Ser 151:103-114

Durbin EG, Campbell, RG, Casas MC, Ohman MD, Niehoff B, Runge J, Wagner M (2003) Interannual variation in phytoplankton blooms and zooplankton productivity and abundance in the Gulf of Maine during winter. Mar Ecol Prog Ser 254:81-100

Fogarty MJ, Myers RA, Bowen KG (2001) Recruitment of cod and haddock in the North Atlantic: a comparative analysis. ICES J Mar Sci 58:952-961

Frank KT, Brickman D (2000) Allee effects and compensatory population dynamics within a stock complex. Can J Fish Aquat Sci 57:513-517

Greenberg DA, Loder JW, Shen WY, Lynch DR, Naimie CE (1997) Spatial and temporal structure of the barotropic response of the Scotian Shelf and Gulf of Maine to surface wind stress. J Geophys Res 102:20897-20915

Hannah CG, Shore JA, Loder JW (2000) The drift-retention dichotomy on Browns Bank: a model study of interannual variability. Can J Fish Aquat Sci 57:2506-2518

Hannah CG, Shore JA, Loder JW, Naimie CE (2001) Seasonal circulation on the western and central Scotian Shelf. J Phys Oceanogr 31:591-615

Head EJH, Brickman D, Harris LR (2005) An exceptional haddock year class and unusual environmental conditions on the Scotian Shelf in 1999. J Plankton Res 27:597-602

Imsland AK, Jónsdóttir ÓDB (2003) Linking population genetics and growth properties of Atlantic cod. Rev Fish Biol Fish 13:1-26

Kane J (1984) The feeding habits of co-occurring cod and haddock larvae. Mar Ecol Prog Ser 16:9-20

Kane J (1993) Variability of zooplankton biomass and dominant species abundance on Georges Bank, 1977-1986. Fish Bull 91:464-474

Lage C, Kuhn K, Kornfield I (2004) Genetic differentiation among Atlantic cod (Gadus morhua) from Browns Bank, and Nantucket Shoals. Fish Bull 102:289-297

Lapolla A, Buckley LJ (2005) Hatch date distributions of young-of-year haddock Melanogrammus aeglefinus in the Gulf of Maine/Georges Bank region: implications for recruitment. Mar Ecol Prog Ser 290:239-249

Loder JW (1980) Topographic rectification of tidal currents on the sides of Georges Bank. J Phys Oceanogr 10:1399-1416

Loder JW, Han G, Hannah CG, Greenberg DA, Smith PC (1997) Hydrography and baroclinic circulation in the Scotian Shelf region: winter versus summer. Can J Fish Aquat Sci 54 (Suppl 1):40-56

Lough RG, Bolz GR (1989) The movement of cod and haddock larvae onto the shoals of Georges Bank. J Fish Biol 35A:71-79

Lough RG, Manning JP (2001) Tidal-front entrainment and retention of fish larvae on the southern flank of Georges Bank. Deep-Sea Res II 48:631-644

Lough RG, Mountain DG (1996) Effect of small-scale turbulence on feeding rates of larval cod and haddock in stratified water on Georges Bank. Deep-Sea Res II 43: 1745-1772

Lough RG, Potter DC (1993) Vertical distribution patterns and diel migrations of larval and juvenile haddock Melanogrammus aeglefinus and Atlantic cod Gadus morhua. Fish Bull 91:281-303

Lough RG, Smith WG, Werner FE, Loder JW and 6 others (1994) Influence of wind-driven advection on interannual variability in cod egg and larval distributions on Georges Bank: 1982 vs 1985. ICES Mar Sci Symp 198:356-378

Lynch DR, Werner FE, Greenberg DA, Loder JW (1992) Diagnostic model for baroclinic, wind-driven and tidal circulation in shallow seas. Cont Shelf Res 12:37-64

Manning JP, Strout G (2001) Georges Bank winds: 1975-97. Deep-Sea Res II 48:115-135

Manning JP, Lough RG, Naimie CE, Churchill JH (2001) Modelling the effect of a slope-water intrusion on advection of fish larvae in May 1995 on Georges Bank. ICES J Mar Res 58:985-993

McGillicuddy DJ Jr, Bucklin A (2002) Intermingling of two Pseudocalanus species on Georges Bank. J Mar Res 60: 583-604

Morse W (1989) Catchability, growth and mortality of larval fishes. Fish Bull 87:417-446

Mountain D, Berrien P, Sibunka J (2003) Distribution, abundance and mortality of cod and haddock eggs and larvae on Georges Bank in 1995 and 1996. Mar Ecol Prog Ser 263:247-260

Myers RA, Cadigan NG (1993) Density-dependent juvenile mortality in marine demersal fish. Can J Fish Aquat Sci 50: 1576-1590

Myers RA, Pepin P (1994) Recruitment variability and oceanographic stability. Fish Oceanogr 3:246-255

Myers RA, Hutchings JA, Barrowman NJ (1996) Hypotheses for the decline of cod in the North Atlantic. Mar Ecol Prog Ser 138:293-308

Naimie CE (1996) Georges Bank residual circulation during weak and strong stratification periods: prognostic numerical model results. J Geophys Res 101 (C3):6469-6486

Northern Demersal and Southern Demersal Working Groups, Northeast Regional Stock Assessment Workshop (2001) Assessment of 19 northeast groundfish stocks through 2000-A report to the New England Fishery Management Council's multi-species monitoring committee. Doc 01-20, Northeast Fisheries Science Center, Woods Hole, MA

O'Boyle RN, Sinclair M, Conover RJ, Mann KH, Kohler AC (1984) Temporal and spatial distribution of ichthyo- 
plankton communities of the Scotian Shelf in relation to biological, hydrological, and physiographic features. Rapp P-V Reun Cons Int Explor Mer 183:27-40

O'Brien L (1999) Factors influencing the rate of sexual maturity and the effect on spawning stock for Georges Bank and Gulf of Maine Atlantic cod Gadus morhua stocks. J Northwest Atl Fish Sci 25:179-203

O'Brien L, Rago PJ, Lough RG, Berrien P (2003) Incorporating early-life history parameters in the estimation of the stock-recruitment relationship of Georges Bank Atlantic cod (Gadus morhua). J Northwest Atl Fish Sci 33: 191-205

Page FH, Frank KT (1989) Spawning time and egg stage duration in Northwest Atlantic haddock (Melanogrammus aeglefinus) stocks with emphasis on Georges and Brown Bank. Can J Fish Aquat Sci 46(Suppl 1):68-81

Page FH, Sinclair M, Naimie CE, Loder JW, Losier RJ, Berrien PL, Lough RG (1998) Cod and haddock spawning on Georges Bank in relation to water residence times. Fish Oceanogr 8:212-226

Pentila JA, Nelson GA, Burnett JM III (1989) Guidelines for estimating lengths at age for 18 Northwest Atlantic finfish and shellfish species. NOAA Tech Mem NMFS-F/NEC 66: 1-39

Petrie BD, Drinkwater K, Gregory D, Pettipas R, Sandstrom A (1996) Temperature and salinity atlas for the Scotian Shelf and the Gulf of Maine. Can Tech Rep Hydrogr Ocean Sci 171: $V+398 p$

Planque B, Frédou T (1999) Temperature and the recruitment of Atlantic cod (Gadus morhua). Can J Fish Aquat Sci 56: 2069-2077

Platt T, Fuentes-Yaco C, Frank KT (2003) Spring algal bloom and larval fish survival. Nature 423:398-399

Polacheck T, Mountain D, McMillan D, Smith W, Berrien P (1992) Recruitment of the 1987 year class of haddock (Melanogrammus aeglefinus): the influence of unusual larval transport. Can J Fish Aquat Sci 49:484-496

Rideout RM, Trippel EA, Litvak MK (2005) Effects of egg size, food supply and spawning time on early life history success of haddock Melanogrammus aeglefinus. Mar Ecol Prog Ser 285:169-180

Ruzzante DE, Taggart CT, Cook D (1998) A nuclear basis of shelf- and bank-scale population structure in northwest

Editorial responsibility: Kenneth Sherman (Contributing Editor), Narragansett, Rhode Island, USA
Atlantic cod (Gadus morhua): Labrador to Georges Bank. Mol Ecol 7:1663-1668

Serchuck FM, Grosslein MD, Lough RG, Mountain DG, O'Brien L (1994) Fishery and environmental factors affecting trends and fluctuations in the Georges Bank and Gulf of Maine Atlantic cod stocks: an overview. ICES Mar Sci Symp 198:77-109

Sherman K, Smith W, Morse W, Berman M, Green J, Ejsymont L (1984) Spawning strategies of fishes in relation to circulation, phytoplankton production, and pulses in zooplankton off the northeastern United States. Mar Ecol Prog Ser 18:1-19

Sibunka JD, Silverman MJ (1984) MARMAP surveys of the continental shelf from Cape Hatteras, North Carolina, to Cape Sable, Nova Scotia (1977-83). Atlas No. 1: summary of operations. NOAA Tech Mem NMFS-F/NEC 33:1-306

Sibunka JD, Silverman MJ (1989) MARMAP surveys of the continental shelf from Cape Hatteras, North Carolina, to Cape Sable, Nova Scotian (1984-87). Atlas No. 3: summary of operations. NOAA Tech Mem NMFS-F/NEC 68:1-197

Smith PC, Flagg CN, Limeburner R, Fuentes-Yaco C, Hannah C, Beardsley RC, Irish JD (2003) Scotian Shelf crossovers during winter/spring 1999. J Geophys Res 108(C11):8013. DOI:10.1029/2001JC001288

Smith WG, Morse WW (1985) Retention of larval haddock Melanogrammus aeglefinus in the Georges Bank region, a gyre-influenced spawning area. Mar Ecol Prog Ser 24: $1-13$

Thompson BM, Riley JD (1981) Egg and larval development studies in the North Sea cod (Gadus morhua L.). Rapp P-V Reun Cons Int Explor Mer 178:553-559

Tripple EA (1998) Egg size and viability and seasonal offspring production of young Atlantic cod. Trans Am Fish Soc 127:339-359

Werner FE, Page FH, Lynch DR, Loder JW, Lough RG, Perry RI, Greenberg DA, Sinclair MM (1993) Influence of mean advection and simple behavior on the distribution of cod and haddock early life stages on Georges Bank. Fish Oceanogr 2:43-64

Wigley SE (1999) Effects of first-time spawners on stockrecruitment relationships for two groundfish species. J Northwest Atl Fish Sci 25:215-218

Submitted: November 17, 2003; Accepted: September 9, 2005 Proofs received from author(s): February 3, 2006 